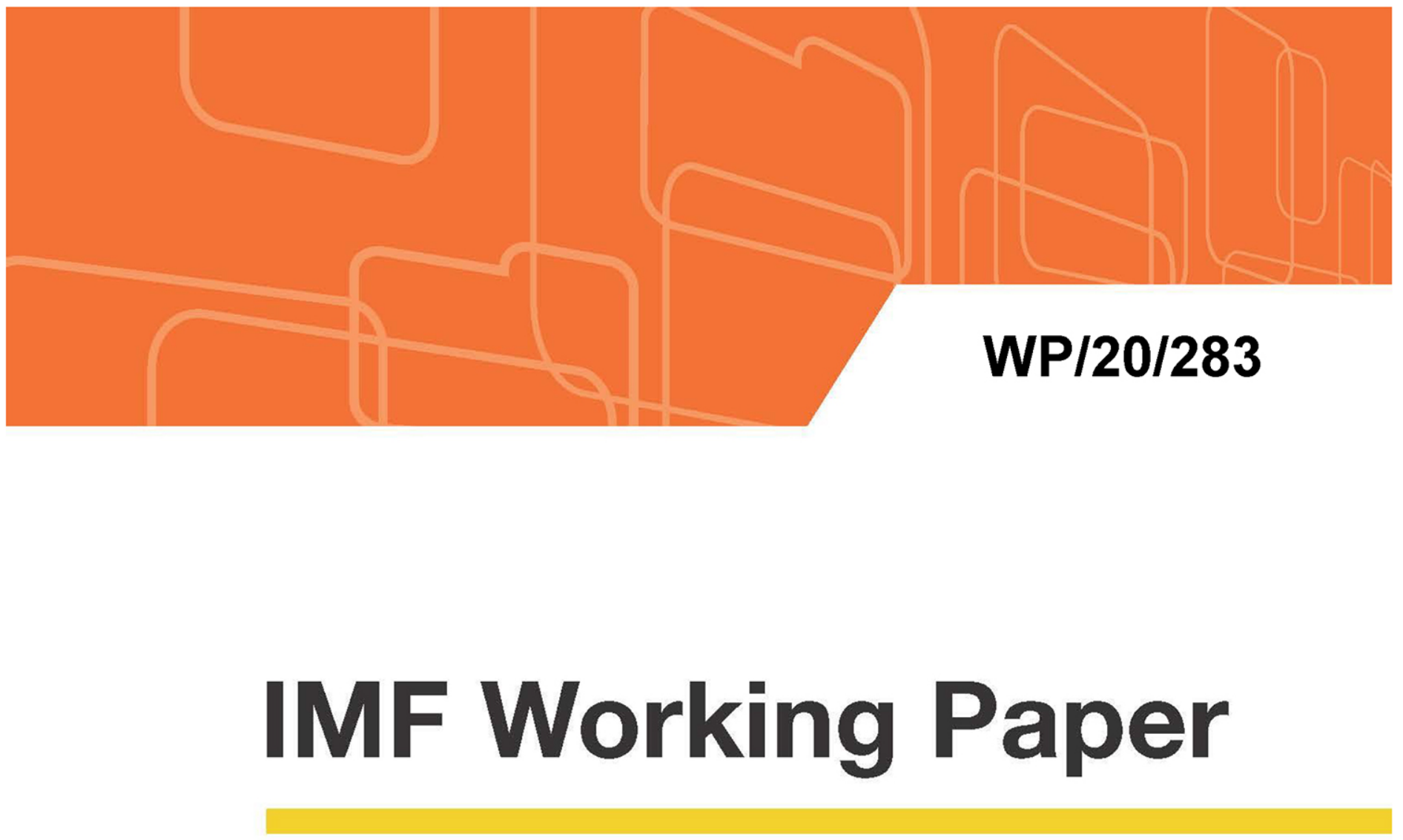

\title{
Exchange Rate Fluctuations and Firm Leverage
}

Ilhyock Shim, Sebnem Kalemli-Özcan, Xiaoxi Liu

IMF Working Papers describe research in progress by the author(s) and are published to elicit comments and to encourage debate. The views expressed in IMF Working Papers are those of the author(s) and do not necessarily represent the views of the IMF, its Executive Board, or IMF management. 


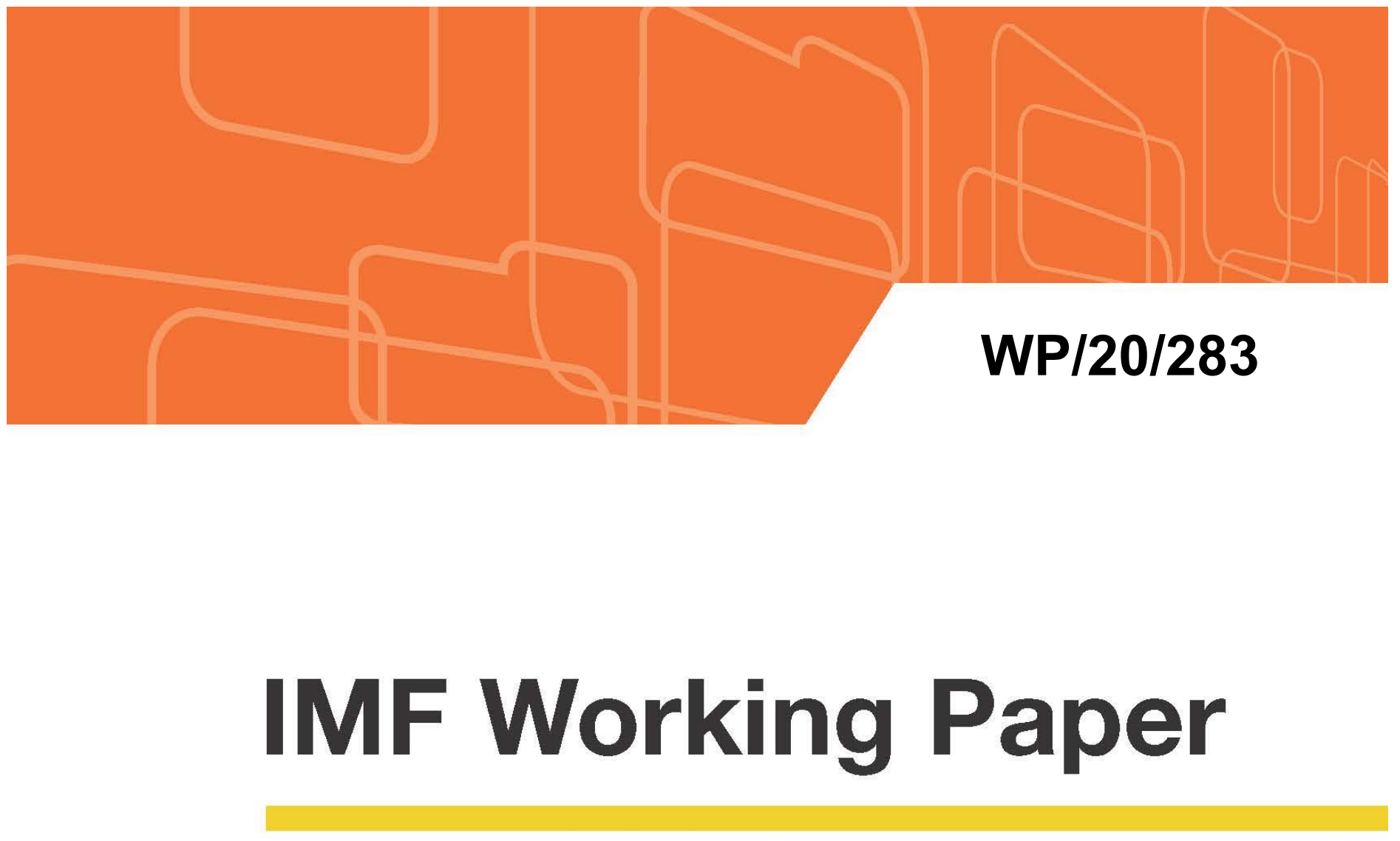

\section{Exchange Rate Fluctuations and Firm Leverage}

Ilhyock Shim, Şebnem Kalemli-Özcan, Xiaoxi Liu

IMF Working Papers describe research in progress by the author(s) and are published to elicit comments and to encourage debate. The views expressed in IMF Working Papers are those of the author(s) and do not necessarily represent the views of the IMF, its Executive Board, or IMF management. 


\title{
IMF Working Paper
}

\author{
Research Department
}

\section{Exchange Rate Fluctuations and Firm Leverage}

Prepared by Ilhyock Shim, Şebnem Kalemli-Özcan, and Xiaoxi Liu

Authorized for distribution by Gita Gopinath

December 2020

\section{IMF Working Papers describe research in progress by the author(s) and are published to} elicit comments and to encourage debate. The views expressed in IMF Working Papers are those of the author(s) and do not necessarily represent the views of the IMF, its Executive Board, or IMF management.

\begin{abstract}
We quantify the effect of exchange rate fluctuations on firm leverage. When home currency appreciates, firms who hold foreign currency debt and local currency assets observe higher net worth as appreciation lowers the value of their foreign currency debt. These firms can borrow more as a result and increase their leverage. When home currency depreciates, the reverse happens as firms have to de-lever with a negative shock to their balance sheets. Using firm-level data for leverage from 10 emerging market economies during the period from 2002 to 2015, we show that firms operating in countries whose non-financial sectors hold more of the debt in foreign currency, increase (decrease) their leverage relatively more after home currency appreciations (depreciations). Combining the leverage data with firm-level FX debt data for 4 emerging market countries, we further show that our results hold at the most granular level. Our quantitative results are asymmetric: the effects of depre-ciations, that are generally associated with sudden stops, are quantitatively larger than those of appreciations, which take place at a slower pace over time during capital inflow episodes. As our exercise compares depreciations and appreciations of similar size, these results are suggestive of financial frictions being more binding during depreciations than a possible relaxation of such frictions during appreciations.
\end{abstract}

JEL Classification Numbers: E0, F0, F1

Keywords: COVID-19; Capital Flows, Exchange Rates, FX Borrowing, Firm Leverage Authors’ E-Mail Addresses: Kalemli@umd.edu; Ilhyock.Shim@bis.org; Amanda.Liu@bis.org 


\title{
Exchange Rate Fluctuations and Firm Leverage*
}

\author{
Sebnem Kalemli-Ozcan \\ Xiaoxi Liu \\ IMF, University of Maryland, NBER, CEPR \\ Bank for International Settlements \\ Ilhyock Shim \\ Bank for International Settlements
}

October 2020

\begin{abstract}
We quantify the effect of exchange rate fluctuations on firm leverage. When home currency appreciates, firms who hold foreign currency debt and local currency assets observe higher net worth as appreciation lowers the value of their foreign currency debt. These firms can borrow more as a result and increase their leverage. When home currency depreciates, the reverse happens as firms have to de-lever with a negative shock to their balance sheets. Using firm-level data for leverage from 10 emerging market economies during the period from 2002 to 2015, we show that firms operating in countries whose non-financial sectors hold more of the debt in foreign currency, increase (decrease) their leverage relatively more after home currency appreciations (depreciations). Combining the leverage data with firmlevel FX debt data for 4 emerging market countries, we further show that our results hold at the most granular level. Our quantitative results are asymmetric: the effects of depreciations, that are generally associated with sudden stops, are quantitatively larger than those of appreciations, which take place at a slower pace over time during capital inflow episodes. As our exercise compares depreciations and appreciations of similar size, these results are suggestive of financial frictions being more binding during depreciations than a possible relaxation of such frictions during appreciations.
\end{abstract}

JEL Classification: E0, F0, F1

Keywords: Capital Flows, Exchange Rates, FX Borrowing, Firm Leverage

*We thank participants in numerous conferences and seminars. We are grateful to Jimmy Shek and Jose Maria Vidal Pastor for research assistance. This article reflects the views of the authors, and does not necessarily reflect those of the IMF or the Bank for International Settlements. 


\section{Introduction}

Standard international macro theory postulates that a small open economy should let its exchange rate carry the burden of adjustment when financial conditions change in the rest of the world. When external demand decreases due to a tightening of monetary policy for example, the associated appreciation in the rest of the world and depreciation in the small open economy help to switch the external demand from the rest of the world to the small open economy's goods. This channel, known as the expenditure switching channel of the MundellFleming model, highlights the virtue of flexible exchange rates. ${ }^{1}$ However, policy makers in emerging market economies (EMEs) argue that flexible exchange rates not help but hurt their economies as exchange rate volatility has negative effects on economic activity due to several channels. One such channel works via the effect of exchange rate fluctuations on foreign currency (FX) debt. ${ }^{2}$ In an economy where agents largely borrow in FX, exchange rate depreciations will lead to higher debt burdens as the value of FX debt grows, while that of local currency assets shrinks. The empirical literature on such balance sheet currency mismatches shows that exchange rate depreciations are contractionary, due to these balance sheet effects. ${ }^{3}$

Interestingly, there is no counterpart to this firm-level empirical literature on currency deprecation-driven balance sheet effects for currency appreciations. This is the task we undertake in this paper. The original theoretical frameworks on balance sheet effects by Calvo (1998) and Krugman (1999) show that the effects should be symmetric for depreciations and appreciations. When home currency appreciates, the balance sheet effect should work in reverse, lowering the value of FX debt, which constitutes a positive net worth shock to the bal-

\footnotetext{
${ }^{1}$ The evidence on such expenditure switching is, however, weak. Under dominant currency pricing, expenditure switching is muted as it works mostly via imports and not exports as shown by Gopinath (2016) and Gopinath, Boz, Casas, Diez, Gourinchas and Plagborg-Moller (2019).

2See Calvo and Reinhart (2002) who document a pervasive "fear of floating," where the "fear" can be linked to liability dollarization. Another argument for preventing exchange rate volatility is the high degree of passthrough into domestic inflation in emerging market economies as argued by Burnstein and Gopinath (2014).

${ }^{3}$ Aguiar (2005), for example, considers the large depreciation episode during the 1995 Mexico debt crisis and finds that firms with heavy exposure to short-term FX debt before the devaluation experienced relatively low levels of post-devaluation investment. Kalemli-Ozcan, Kamil and Villegas-Sanchez (2016), using also firmlevel data from six Latin American countries, show that non-exporters with a balance sheet currency mismatch decrease investment as argued by Aguiar (2005), but that foreign-owned exporters with access to liquidity from their parents increase investment after currency crises in these countries. See also Serena and Sousa (2017) who show similar results for 36 emerging market economies. Bleakley and Cowan (2008) argue that exporters will not have a balance sheet currency mismatch due to their natural hedge of revenue in foreign currency. This might change if exporters are also importers since another channel for the contractionary effects of depreciations is imported intermediate inputs, where such inputs will be more expensive after a depreciation as shown in Mendoza and Yue (2012) and Gopinath and Neiman (2013).
} 
ance sheets of firms. This allows firms to borrow more, leading to a credit expansion and an investment boom in the economy. An alternative way of modeling the expansionary effects of appreciations is through credit supply of global banks. If these banks' balance sheets suffer from currency mismatches with liabilities in US dollars exceeding assets in US dollars, as argued by Bruno and Shin (2015a), then they will extend more credit globally as a result of relaxation of their value-at-risk constraint when the US dollar depreciates and other economies' currencies appreciate vis-a-vis the US dollar. ${ }^{4}$ However, there are also papers, such as Aghion, Bacchetta and Banerjee (2000, 2001), Céspedes, Chang and Velasco (2004) and Mendoza (2010), that show asymmetric effects. In these models the balance sheet effects only work with depreciations and not with appreciations due to firms' occasionally binding constraints during depreciations. Thus, these models suggest that regulation/policy should prevent an increase in firm leverage during appreciation episodes.

We empirically investigate whether or not appreciation- and depreciation-driven balance sheet effects work in a similar way. Specifically, we ask whether firms reduce their leverage with depreciations and increase their leverage with appreciations and whether policies aimed at limiting exchange rate fluctuations, such as foreign exchange interventions (FXI) have any effect on firm leverage.

We use firm-level data from the ORBIS database for 10 EMEs in Asia over the period from 2002 to 2015. The ORBIS database allows us to have a granular look since it includes balance sheet variables for both listed and non-listed firms. This is a big advantage over other firmlevel datasets such as Worldscope which covers only listed firms, and the Capital IQ database which has an extremely small coverage of non-listed firms (a few giant firms in most EMEs). Another advantage of using data on private firms is that leverage will be evaluated at the book value and hence there will not be a mechanical effect on leverage with the changes in exchange

\footnotetext{
${ }^{4}$ Bruno and Shin (2015b), using bank-level data, provide evidence that a depreciation of the US dollar against many countries' currencies is associated with an increase in the leverage of global banks and an acceleration of cross-border banking flows into countries whose home currencies appreciate against the US dollar. Avdjiev, Koch and Shin (2018) show similar evidence that cross-border banking flows are higher when there are depreciations in major funding currencies. On the pricing side, Hofmann, Shim and Shin $(2017,2019)$ show that an appreciation of local currency vis-à-vis the US dollar in EMEs leads to a compression in government bond yields of those EMEs, which signals easier borrowing conditions for governments. See also Avdjiev, Du, Koch and Shin (2019) and Avdjiev, Bruno, Koch and Shin (2018) with similar results on prices. The literature still lacks evidence at the firm-level on the direct effects of local currency appreciations on firms' borrowing, a gap that our paper tries to bridge.
} 
rates. $^{5}$

ORBIS data may not be representative nationally due to the fact that it does not cover the universe of private firms. Thus, we will focus on 10 Asian EMEs with good coverage of the economy (over 45/50 per cent of aggregate output and corporate sector debt), as shown in Table 1.6

Table 1: Coverage of Firm-Level Data

\begin{tabular}{|c|c|c|}
\hline Economy & $\begin{array}{l}\text { Aggregated Firm Sales/ } \\
\text { Country Gross Output }{ }^{1}\end{array}$ & $\begin{array}{l}\text { Aggregated Firm Debt/ } \\
\text { Country Corporate Sector Debt }\end{array}$ \\
\hline China & $59 \%$ & $23 \%$ \\
\hline Hong Kong SAR & $33 \%$ & $15 \%$ \\
\hline Indonesia & $48 \%$ & $47 \%$ \\
\hline India & $45 \%$ & $71 \%$ \\
\hline Korea & $50 \%$ & $51 \%$ \\
\hline Malaysia & $69 \%$ & $91 \%$ \\
\hline Philippines & $45 \%$ & $85 \%$ \\
\hline Singapore & $49 \%$ & $61 \%$ \\
\hline Thailand & $70 \%$ & $77 \%$ \\
\hline Chinese Taipei & $67 \%$ & $83 \%$ \\
\hline \multicolumn{3}{|c|}{$\begin{array}{l}\text { This table shows the coverage of the ORBIS database. Data sources: BIS; CEIC; ADB; World KLEMS; nationa } \\
\text { data. } \\
{ }^{1} \text { This column shows the aggregated sales of all firms in our sample divided by the nominal gross output. The } \\
\text { coverage numbers are calculated in every year from } 2002 \text { to } 2015 \text {. The table reports the average of the yearly } \\
\text { numbers for each economy. The gross output data are from World KLEMS for India and Korea, from CEIC } \\
\text { for China and Indonesia, and from ADB and national statistics for Hong Kong SAR, Malaysia, the Philippines } \\
\text { Singapore, Thailand and Chinese Taipei. } \\
2 \text { This column shows the aggregated debt outstanding of all firms in our sample divided by the national tota } \\
\text { credit to the private non-financial corporate sector. The denominator is from the BIS. The coverage numbers are } \\
\text { calculated in every year from } 2002 \text { to } 2015 \text {. The table reports the average of the yearly numbers for each economy }\end{array}$} \\
\hline
\end{tabular}

It is hard to obtain currency composition of debt at the firm level for private firms in any country unless a credit registry is used. These registries include firms' and banks' regulatory filings to the national authorities. In the aggregate form, such data can partly be obtained from banks reporting to the BIS, through the BIS Global Liquidity Indicators (GLI) database. The GLI database is based on BIS Locational Banking Statistics and BIS International Debt Se-

\footnotetext{
${ }^{5}$ See Adrian and Shin (2013) on the different cyclical properties of book leverage and market leverage. Although we do not have a mechanical valuation effect on firm leverage due to higher valued foreign currency assets when foreign currency appreciates and vice versa on debt, we have an accounting problem due to conversion of FX values to local currency. Under the accounting practise IAS 21 in IFRS standards that our sample economies use, the book values of foreign currency debt/assets are transalated to local currency using the periodend exchange rates in firm balance sheets. Thus, with a 10 percent depreciation a 100 dollar loan that was booked as 100 pesos in local currency before the peso deprecation, will now be booked as 110 pesos in local currency although there is no new 10-peso local currency debt. This has to be adjusted to the original value of 100 dollars. We adjust for this "accounting effect" and show that it does not affect our results.

${ }^{6}$ The only exceptions are China and Hong Kong SAR. We ran robustness exercises without including these two economies, and obtained similar results. Notice that the coverage of aggregate output and aggregate corporate sector debt in Worldscope data and in Capital IQ data will be much lower, around 10 per cent, for all our sample economies due to the focus of these data sets on listed firms.
} 
curities Statistics. This database provides FX debt exposures for both bonds and loans. As the database is at the aggregate level, firms', households' and governments' FX debt is aggregated into the total FX debt of the non-financial sector of a given country. Through another BIS dataset, we can separate the government sector and keep the non-financial sector as firms and households. This is important as results on the effects of appreciations change with and without government debt.

FX bonds are debt securities issued in the US dollar, euro and Japanese yen and issued in international markets by the residents in the non-financial sector of a given economy. FX loans are bank loans extended to the non-bank sector of a given economy both by domestic banks and international banks located outside the economy and denominated in the US dollar, euro and Japanese yen. The BIS GLI data cover 42 economies, 21 of which are advanced economies (AEs) and the rest are EMEs. The share of total FX debt of our 10 EMEs out of the 21 EMEs with FX debt data available in the GLI database was $42 \%$ in 2000 , and reached to $65 \%$ in 2015 . The average share during the whole sample period is $53 \%$. Thus, our sample of 10 EMEs accounts for a dominant share of global EME FX debt.

As Table 2 shows, for all our sample economies, FX loans constitute the larger share of FX debt of the non-financial sector over time. This is because FX loans can be obtained both from domestic and external lenders, whereas FX bonds are predominantly issued internationally. Since most small firms cannot issue internationally (and most of the private firms are small), studying effects of FX debt exposure through international bond issuance, as common in the literature due to data availability issues, will underestimate the "true" FX debt exposure of a given country.

Most of the papers in the literature so far consider either FX loans or FX bonds to capture FX debt of a country, but not both of these asset classes, which is done first in our paper. For example, Maggiori, Neiman and Schreger (2018) analyze only FX bonds issued by the non-financial sector, and do not consider FX loans. At the other extreme, Avdjiev, Bruno, Koch and Shin (2018) consider only dollar-denominated cross-border loans to EMEs. Lane and Shambaugh (2010) and Bénétrix, Lane and Shambaugh (2015) consider both FX loans and FX bonds, but their approach is based on "estimates" and not real exposures. They combine BIS and IMF balance of payments data in order to obtain "estimates" for a large cross-section of countries only for cross-border FX exposures and not total FX exposures. We have a limited set of countries compared to those papers but use data on "actual" FX exposures to both domestic 
Table 2: Share of FX Loans in FX Debt

\begin{tabular}{ccccccccccc}
\hline & China & $\begin{array}{c}\text { Hong } \\
\text { Kong SAR }\end{array}$ & Indonesia & India & Korea & Malaysia & Philippines & Singapore & Thailand & Chinese \\
Taipei
\end{tabular}

This table shows the share of FX loans in total FX debt (including loans and bonds) of the non-financial sector. Data source: BIS.

and foreign lenders.

In order to estimate the "share" of FX debt in total debt of the non-financial sector, we use the BIS Total Credit database. This database provides data on total loans and debt securities used for borrowing by the residents in the non-financial sector of a given economy, both in domestic and foreign currencies and from both domestic and foreign lenders. By dividing the sum of loans and bonds in FX from the GLI data set for the non-financial sector by the sum of total loans and bonds for the non-financial sector from the Total Credit database, we obtain the country-level non-financial sector FX debt share.

We run a firm-level leverage regression using annual data, where we regress firm-level leverage on firm fixed effects, standard firm leverage controls and the country-level nonfinancial sector FX debt share. We interact this FX debt exposure with dummies for exchange rate depreciation and appreciation in excess of 0,5 and 10 per cent. We do this, instead of using continuous changes in the exchange rate, to be able to separate the quantitative impact of depreciations from appreciations in the light of the theoretical literature reviewed above. ${ }^{7}$ We find that when home currency appreciates (depreciates), firms operating in the countries whose non-financial sectors hold a larger share of their debt in FX, increase (decrease) their leverage relatively more than those in countries with smaller FX debt shares. We show that our results are predominantly driven by FX loan exposures rather than FX bond exposures, which is not surprising given the fact that most of our firms are small and these firms will mainly borrow in FX loans from their domestic banks rather than issuing FX bonds in interna-

\footnotetext{
${ }^{7}$ We use continuous changes in the exchange rate as a robustness check.
} 
tional markets.

In terms of economic significance, we find the effect of deprecations to be larger than that of appreciations, so our results are asymmetric as argued by the literature on occasionally binding constraints. In the data, such an effect can be identified from within firm variation during large depreciation events (sudden stops in a given year), whereas appreciations happen slowly during booms when a typical capital inflows bonanza lasts 2 to 3 years. To make sure our results are not driven by this type of variation in the data, we compare similarly sized depreciations and appreciations. Using the mean ratio of FX debt to total debt for the 10 sample economies, we find that a depreciation of 10 per cent or more decreases leverage by 0.1517 and the effect of a 10 percent or more appreciation is an increase in leverage of 0.0265 . Given the mean firm leverage is 0.16 , a 10 percent or more depreciation represents a 90 percent decline in leverage relative to its mean, whereas a 10 percent or more appreciation represents a 20 percent increase in leverage over its mean, still a sizeable effect.

Possible threats to our identification are through omitted time-varying factors if these factors are correlated with the country-time level exchange rate fluctuations interacted with the share of corporate sector FX debt. One possibility is terms-of-trade shocks. To check the role of these factors, we use country $\times$ time fixed effects by re-defining FX debt at the firm level so that our country level FX debt interacted with the exchange rate changes are not absorbed by country $\times$ time fixed effects.

We follow two approaches to bring firm-level FX debt into our analysis. First, we use a proxy firm-level measure, where we proxy the level of firm-level FX debt by assuming that each firm's FX debt share is equivalent to the corporate sector's FX debt share, and back out the level of firm-level FX debt out of total firm-level debt by using the corporate sector FX debt share. We control for time-varying firm size as larger firms will have larger FX debts by construction in this approach. Assuming each firm's FX debt share being constant and equal to the corporate sector's share of FX debt is of course a big assumption and this exercise cannot replace having actual data on firm-level FX debt levels and shares. However, econometrically it solves a huge problem as it allows us to control for time-varying unobserved heterogeneity at the country level by using country $\times$ time fixed effects. The omitted variables at the countrytime level will be correlated with the exchange rate fluctuations and country-level FX debt shares and they need to be absorbed through the use of country $\times$ time fixed effects for our identification strategy to remain valid. 
Our second approach is to use actual data on firm-level FX debt share, though this will be only for 4 countries given the data availability. We obtain similar results to our benchmark results from both of these approaches. We further explore the role of firms operating in nontradeable sectors for possible selection effects and also rerun our regressions by separating long-term and short-term debt. We also run a placebo exercise where we use very small levels of deprecations and appreciations (less than 1 per cent) and show that there are no effect of such small movements in the exchange rate on firm leverage.

Finally, we study the role of policy in limiting or exacerbating leverage via moral hazard by focusing on FXI policies that are aimed at smoothing exchange rate fluctuations. In our sample of 10 EMEs, we find a negative effect of FXI on leverage. That is, firms in countries that increase FXI, decrease their leverage over time conditional on other determinants of leverage including the effect of exchange rate fluctuations. As the theoretical literature argues for moral hazard effects of FXI on firms' risk taking in terms of increasing their FX debt (e.g. Diamond, Hu and Rajan (2018)), we checked our results in a larger set of countries since the effects of FXI on leverage might differ across firms and across countries. In the larger sample of 42 countries, we find that the effect of FXI on firm leverage turns out to be largely insignificant. ${ }^{8}$

The paper proceeds as follows. Section 2 describes the data and presents stylized facts. Section 3 presents the empirical methodology, benchmark results and robustness exercises. Section 4 concludes.

\section{Data and Stylized Facts}

\subsection{Firm-Level Financial Data}

Our study uses accounting data of non-financial firms for the period of 2002 to 2015 in the following 10 economies: China, Chinese Taipei, Hong Kong SAR, India, Indonesia, Korea, Malaysia, the Philippines, Singapore and Thailand. We obtain annual data on firm-level balance sheet items such as total assets, total debt, long-term debt, short-term debt, sales, tangible

\footnotetext{
${ }^{8}$ We find a marginally positive significant effect only in countries with high levels of FX debt at the beginning of the sample. Note that our results differ from those of Tong and Wei (2019) who find a very strong positive effect of FXI on firm leverage. We believe this is due to the small and select sample Tong and Wei (2019) use as they only focus on listed firms, whereas we have a much larger sample including private firms. Listed firms may increase their leverage as a result of FXI but this does not mean country-level corporate sector leverage will be higher. The listed firms will not be representative of the corporate sector leverage in EMEs as they represent a small share of the corporate sector given less developed stock markets in these economies.
} 
fixed assets and earnings before interest and taxes (EBIT) from the ORBIS database produced by Bureau van Djik. Exchange rate data come from the BIS.

An important feature of our data is that it contains not only publicly traded companies, but also privately held firms which represent the majority of GDP for many economies in the sample. We exclude from the sample the firms inactive during the sample period and those in bankruptcy procedures. By taking advantage of the ownership and headquarter information provided in the ORBIS database, we also exclude those firms that are part of multinational networks, where decision making will be governed elsewhere than the firms' financial reporting location. ${ }^{9}$ For example, a branch of a Korean company located in China reports the financial information to China. Such a branch is excluded from our sample because its decisions have little to do with the fluctuations in the value of the Chinese yuan against the US dollar. To avoid double counting, we use unconsolidated financial information for the firms reporting both consolidated and unconsolidated information. We further clean up the financial data following the procedures described in Kalemli-Ozcan, Sorensen, Villegas-Sanchez, Volosovych and Yesiltas (2015).

We combine the cleaned financial data from the ORBIS database and the country-level nominal bilateral exchange rate data synchronized with each country's fiscal year applied to financial reporting. The fiscal year of the financial data reported before June is assigned to the year before the reporting-end year. The unit of observation in the sample is "firm-year". Our final sample contains 1,661,677 firm-year observations. Table 3 shows the number of observations and descriptive statistics of the main variables in the final sample after winsorization. All the variables are winsorized at 1 per cent to control for outliers before it is used in the regressions, while Sales growth is windsorized at 5 per cent.

Our dependent variable is a firm's financial leverage measured by the book value of total financial debt scaled by the book value of total assets. Total financial debt is the total value of the outstanding bank loans and financial bonds at the end of the fiscal year. We prefer not to use the book value of total liabilities as the main measure of firm leverage in our benchmark analysis. This is because such liabilities contain information on trade credits or other forms of liabilities such as pension liabilities. Though, using these alternative measures of leverage for

\footnotetext{
${ }^{9}$ We exclude from the sample the firms that are identified as "branches of foreign companies" and those with their headquarters or ultimate parents located outside the financial reporting country in terms of the ISO country code.
} 
Table 3: Summary Statistics ${ }^{+}$

\begin{tabular}{llccrcc}
\hline Variables & \multicolumn{1}{c}{ Firm-year obs. } & Mean & St. Dev. & Min. & Median & Max. \\
\hline Leverage & $1,661,677$ & 0.162 & 0.241 & 0.000 & 0.000 & 0.998 \\
Collateral & $1,661,677$ & 0.319 & 0.269 & 0.000 & 0.258 & 0.985 \\
Profitability & $1,661,677$ & 0.077 & 0.175 & -0.521 & 0.052 & 0.938 \\
Size & $1,661,677$ & 0.815 & 1.906 & -3.444 & 0.681 & 6.373 \\
Sales growth & $1,661,677$ & 0.267 & 0.580 & -0.464 & 0.120 & 1.993 \\
\hline
\end{tabular}

${ }^{\dagger}$ Based on unbalanced and winsorized sample of firms in 10 Asian economies.

robustness delivers broadly similar results.

We create dummy variables for exchange rate appreciations and depreciations. Dummy $\Delta e_{c, t}^{k}$ equals 1 when the nominal exchange rate against the US dollar decreases (i.e. the home currency appreciates) or increases (i.e. the home currency depreciates) between the end of the previous fiscal year and the end of the current fiscal year by more than $k$, where $k$ takes values of 0,5 and 10 per cent.

Following Rajan and Zingales (1995), we use other control variables that are typical for leverage regressions, such as Collateral measured by tangible fixed assets/total assets, Profitability measured by the EBIT / total assets, Size measured by the logarithm of total assets, and Sales growth measured by the growth in sales. ${ }^{10}$ For all firms in our sample, total debt and other financial variables reported in local currency are converted into the US dollar by using the bilateral exchange rates of the nearest quarter-end of the reporting date. All the control variables are lagged by one year relative to the dependent variable.

\subsection{Non-Financial Sector FX Debt}

Figure 1 shows that the ratio of total corporate debt to GDP has increased over time, especially in EMEs. We want to decompose this increase in corporate sector debt into FX and local currency components, regardless of the lender.

As explained in the introduction, we start with the entire non-financial sector FX debt share as the sum of FX loans and FX bonds in the non-financial sector of a given country (from the GLI database of the BIS) divided by total debt (loans and bonds) of the non-financial sector

\footnotetext{
${ }^{10}$ In the literature, the market-to-book value or Tobin's $Q$ is typically used to control a firm's growth opportunity. Since this is not available for non-listed firms in our sample, we use sales growth as a proxy for growth opportunity.
} 
of the same country (from the Total Credit database of the BIS). Hence this share includes households, corporates and governments.

Figure 2 shows this FX debt share for different regions using the entire GLI database for comparison to Asia where our 10 EMEs are from. This figure calculates the weighted average by using each country's FX debt as the weight. Under this weighting scheme, an economy with a larger amount of FX debt receives a greater weight since that economy is more likely to create instability in the region. Overall, the Latin American countries have the highest level of the FX debt share, though declining over time, while the advanced economies have the lowest level. The Asian EMEs are somewhere in between.

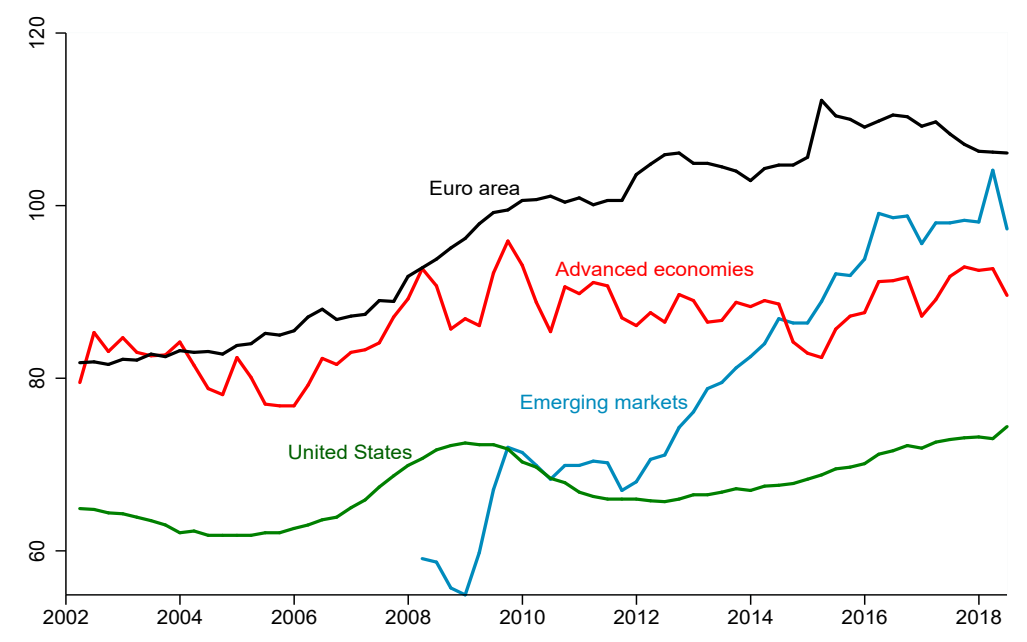

Figure 1: Ratio of Corporate Debt over GDP

This figure shows the ratios of total credit to the non-financial corporate sector over GDP, in per cent. For advanced economies, emerging market economies and the euro area, the ratios are calculated as the aggregated corporate debt divided by the aggregated GDP of all economies in the region. Data source: BIS. 


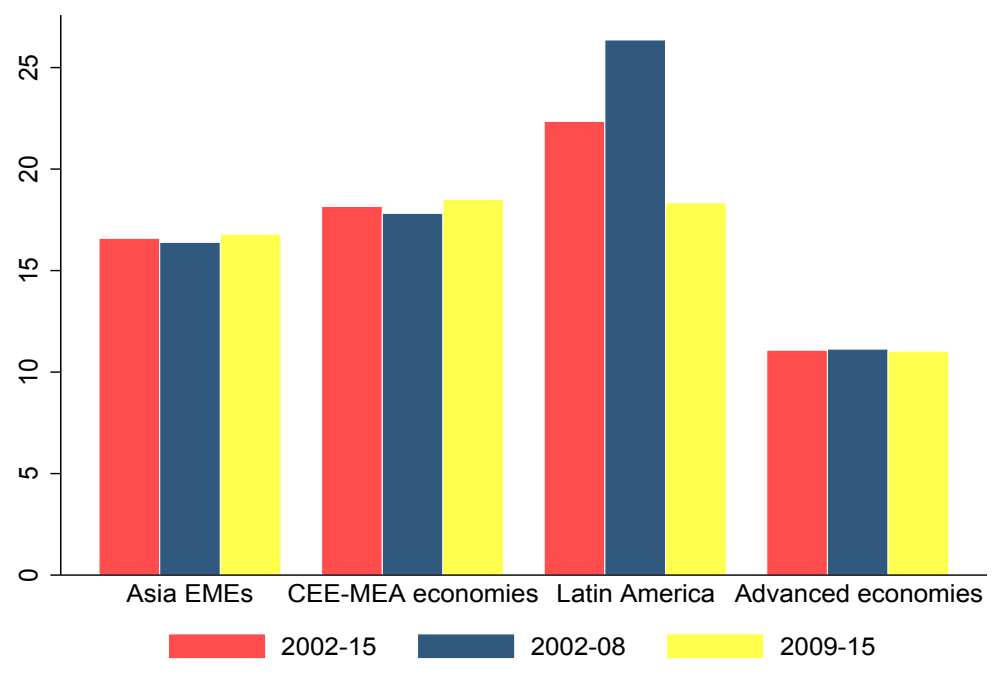

Figure 2: FX Debt Share in Total Non-Financial Sector Debt by Region (II)

This figure shows the weighted average of the ratio of FX debt to total credit to the non-financial sector of 42 economies in four different regions, using the economies' FX debt as the weight. Data source: BIS.

As explained above, we want to obtain corporate sector FX debt. The non-financial sector includes non-financial corporations, households and government. Since we assume that households cannot issue FX bonds (but they can borrow in FX loans), we can calculate the amount of FX bonds issued by non-financial corporates by deducting the FX bonds issued by the government from total FX bonds of the non-financial sector. We can also take out total debt of the government from the denominator. Doing this, we end up with Figure 3 that shows the ratio of FX bonds issued by corporates to total credit to corporates. It seems that FX exposure in bonds is not large relative to total credit that includes loans to the corporate sector. These patterns imply that our results will mainly be driven by FX loan exposures. 


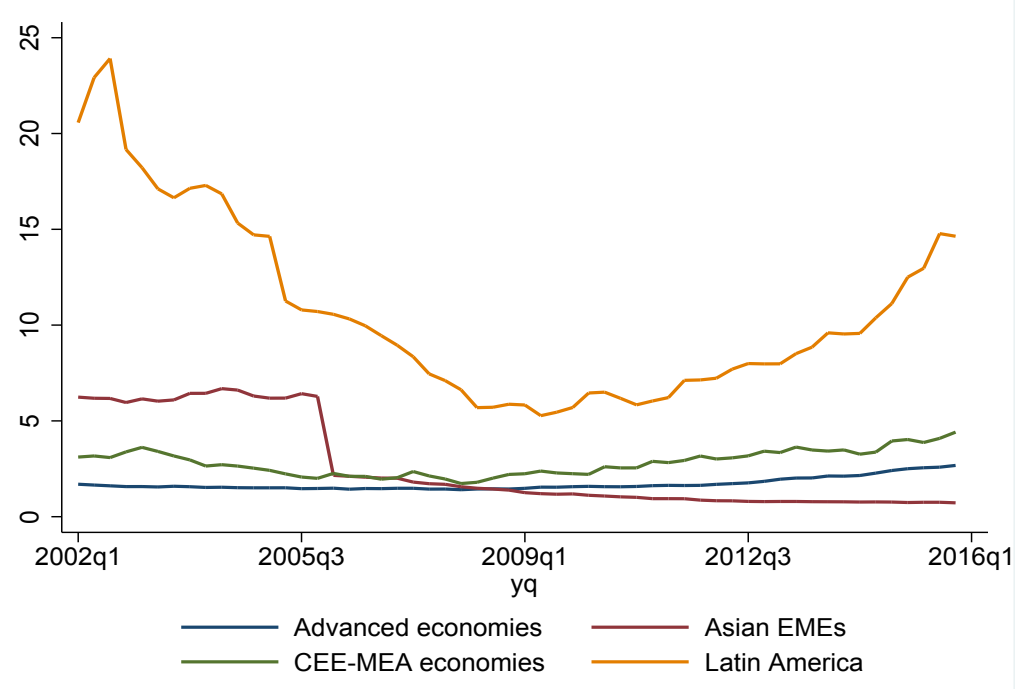

Figure 3: FX Bond Share in Total Debt: Corporate Sector

Table 4 shows the values of the share of FX debt in each of our sample economies for two points in time: the beginning and end of our sample. There is both cross-country and timeseries variation in the extent of non-financial sector FX debt shares, which will be useful for our empirical analysis.

Table 4: FX Debt/Total Non-Financial Sector Debt, 2002 vs 2015

\begin{tabular}{lrr|lrr}
\hline \multicolumn{2}{c}{$2002 Q 1$} & $2015 Q 4$ & & $2002 Q 1$ & $2015 Q 4$ \\
\hline China & 3.87 & 2.09 & Hong Kong SAR & 31.55 & 47.35 \\
Indonesia & 11.13 & 26.45 & India & 1.97 & 4.45 \\
Korea & 4.76 & 3.68 & Malaysia & 10.06 & 3.06 \\
Philippines & 35.18 & 22.08 & Singapore & 28.33 & 28.32 \\
Thailand & 12.76 & 7.93 & Chinese Taipei & 4.69 & 4.48 \\
\hline
\end{tabular}

This table shows the level of the FX debt shares at the end of Q1 2002 and at the end of Q4 2015 in per cent. Data source: BIS. 


\section{Empirical Analysis: Firm Level Regressions}

\subsection{Aggregate FX Debt}

Our macro-level (as we use country-level FX debt) specification (for firm $i$ in industry $j$ and country $c$ in year $t$ ) is as follows:

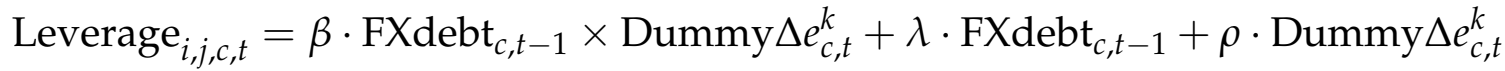

$$
\begin{aligned}
& +\theta \cdot X_{i, c, t-1}+\alpha_{i}+\gamma_{c}+\phi_{j, t}+\varepsilon_{i, j, c, t}
\end{aligned}
$$

where Leverage $e_{i, j, c, t}$ is the firm-level financial leverage measured by financial debt/assets. $X_{i, c, t-1}$ is the set of lagged control variables that are firm size, collateral, profitability and sales growth, i.e., standard determinants of firm leverage. $\alpha_{i}$ captures the firm fixed effects, while $\gamma_{c}$, and $\phi_{j, t}$ are the country and industry-year fixed effects, respectively, which capture countrylevel time-invariant factors such as average differences across countries and also industrylevel time-varying shocks which matter to a great extent for firm-level leverage. Notice that these industry-year effects are at a very granular 4-digit level and hence will also capture most of firm demand shocks as long as those shocks are specific to the 4-digit industry that the firm operates in. These granular 4-digit sector-year fixed effects will also capture supply shocks such as terms-of-trade shocks that will affect firms in tradeable sectors differentially.

The FX debt variable is the share of FX debt in the total debt of the non-financial sector as we have explained above and it is lagged. Hence this variable is at the country level. Dummy $\Delta e^{k}$ is a dummy variable for depreciations and appreciations that takes a value of 1 in years where the bilateral US dollar exchange rate, $e$, appreciates or depreciates more than $k$ per cent, where $k$ will be 0,5 or 10 . So we define the exchange rate, $e$, as local currency divided by the US dollar. Both of these variables, the FX debt share and exchange rate changes, vary at the countrytime level, preventing us from using country-time fixed effects to capture other country-level shocks and policy changes. We estimate the regression model using the ordinary least squares (OLS) method with standard errors clustered at the firm level. ${ }^{11}$ We also conducted a dynamic system general method of moments (GMM) estimation and obtained similar results.

Table 5 presents benchmark results. Columns (1)-(3) show the case for depreciations and columns (4)-(6) that for appreciations. As expected, when the exchange rate depreciates, lever-

\footnotetext{
${ }^{11}$ The results are robust to clustering standard errors at the country level.
} 
age goes down and when it appreciates it goes up. But this only happens in countries whose corporate sectors are heavily indebted in FX. In fact the effect of depreciations and appreciations in countries with no FX debt is the opposite: firm-leverage increases with depreciations and decreases with appreciations, though the effects are small. The effect of FX debt on leverage in the absence of exchange rate movements is always positive. All the other determinants of firm-level leverage enter into the regression with the expected signs.

The effects are economically significant: To calculate the total effects, we use the mean ratio of FX debt to total debt for the 10 Asian economies (0.1519) and show that a 10 percent or more depreciation decreases firm leverage by 0.0844 . Also, the effects tend to become larger with the size of depreciations and appreciations. In general, the effect of deprecations is larger than that of appreciations, and appreciations larger than 10 per cent deliver the wrong sign on the estimated coefficient as shown in the first line of column (6) in Table 5.

Table 5: Benchmark Results

Dependent variable: Financial debt/assets $i_{i, j, c, t}$

\begin{tabular}{|c|c|c|c|c|c|c|}
\hline$\Delta e^{k}$ & $\begin{array}{c}(1) \\
k \geq+0 \%\end{array}$ & $\begin{array}{c}(2) \\
k \geq+5 \%\end{array}$ & $\begin{array}{c}(3) \\
k \geq+10 \%\end{array}$ & $\begin{array}{c}(4) \\
k \leq-0 \%\end{array}$ & $\begin{array}{c}(5) \\
k \leq-5 \%\end{array}$ & $\begin{array}{c}(6) \\
k \leq-10 \%\end{array}$ \\
\hline FXdebt $_{c, t-1} \times$ Dummy $\Delta e_{c, t}^{k}$ & $\begin{array}{c}-0.0484^{* * *} \\
(-6.5)\end{array}$ & $\begin{array}{c}-0.0805^{* * * *} \\
(-9.3)\end{array}$ & $\begin{array}{c}-0.5312^{* * *} \\
(-19.0)\end{array}$ & $\begin{array}{c}0.0492^{* * *} \\
(6.6)\end{array}$ & $\begin{array}{c}0.0816^{* * *} \\
(10.8)\end{array}$ & $\begin{array}{c}-0.2620^{* * * *} \\
(-10.8)\end{array}$ \\
\hline $\mathrm{FXdebt}_{c, t-1}$ & $\begin{array}{c}2.3841^{* * *} \\
(76.4)\end{array}$ & $\begin{array}{c}2.3751^{* * *} \\
(75.3)\end{array}$ & $\begin{array}{c}2.4440^{* * *} \\
(78.4)\end{array}$ & $\begin{array}{c}2.3328^{* * *} \\
(69.6)\end{array}$ & $\begin{array}{c}2.3279^{* * * *} \\
(68.5)\end{array}$ & $\begin{array}{l}2.4123^{* * *} \\
(71.5)\end{array}$ \\
\hline Dummy $\Delta e_{c, t}^{k}$ & $\begin{array}{c}0.0189^{* * * *} \\
(23.0)\end{array}$ & $\begin{array}{c}0.0324^{* * *} \\
(35.1)\end{array}$ & $\begin{array}{c}0.0699^{* * *} \\
(43.0)\end{array}$ & $\begin{array}{c}-0.0184^{* * *} \\
(-22.5)\end{array}$ & $\begin{array}{c}-0.0108^{* * *} \\
(-19.9)\end{array}$ & $\begin{array}{c}0.0132^{* * *} \\
(7.6)\end{array}$ \\
\hline Profitability $_{i, j, c, t-1}$ & $\begin{array}{c}-0.0441^{* * *} \\
(-23.6)\end{array}$ & $\begin{array}{c}-0.0442^{* * *} \\
(-23.7)\end{array}$ & $\begin{array}{c}-0.0441^{* * *} \\
(-23.6)\end{array}$ & $\begin{array}{c}-0.0441^{* * *} \\
(-23.6)\end{array}$ & $\begin{array}{c}-0.0441^{* * *} \\
(-23.6)\end{array}$ & $\begin{array}{c}-0.0442^{* * *} \\
(-23.6)\end{array}$ \\
\hline Collateral $_{i, j, c, t-1}$ & $\begin{array}{c}0.0650^{* * *} \\
(34.7)\end{array}$ & $\begin{array}{c}0.0652^{* * *} \\
(34.9)\end{array}$ & $\begin{array}{c}0.0661^{* * *} \\
(35.3)\end{array}$ & $\begin{array}{c}0.0650^{* * *} \\
(34.7)\end{array}$ & $\begin{array}{c}0.0644^{* * *} \\
(34.4)\end{array}$ & $\begin{array}{c}0.0653^{* * *} \\
(34.8)\end{array}$ \\
\hline $\operatorname{Size}_{i, j, c, t-1}$ & $\begin{array}{c}0.0204^{* * *} \\
(28.4)\end{array}$ & $\begin{array}{c}0.0202^{* * *} \\
(28.2)\end{array}$ & $\begin{array}{c}0.0200^{* * *} \\
(27.9)\end{array}$ & $\begin{array}{c}0.0204^{* * *} \\
(28.4)\end{array}$ & $\begin{array}{c}0.0204^{* * *} \\
(28.4)\end{array}$ & $\begin{array}{c}0.0209^{* * * *} \\
(29.3)\end{array}$ \\
\hline Sales growth ${ }_{i, j, c, t-1}$ & $\begin{array}{c}-0.0009^{* * * *} \\
(-3.1)\end{array}$ & $\begin{array}{c}-0.0009^{* * * *} \\
(-3.2)\end{array}$ & $\begin{array}{c}-0.0009^{* * * *} \\
(-3.2)\end{array}$ & $\begin{array}{c}-0.0009^{* * * *} \\
(-3.1)\end{array}$ & $\begin{array}{c}-0.0010^{* * * *} \\
(-3.4)\end{array}$ & $\begin{array}{c}-0.0009^{* * * *} \\
(-3.0)\end{array}$ \\
\hline Firm FE & Yes & Yes & Yes & Yes & Yes & Yes \\
\hline Country FE & Yes & Yes & Yes & Yes & Yes & Yes \\
\hline Industry-Year FE & Yes & Yes & Yes & Yes & Yes & Yes \\
\hline $\begin{array}{l}\text { Observations } \\
R^{2}\end{array}$ & $\begin{array}{c}1,373,080 \\
0.78\end{array}$ & $\begin{array}{c}1,373,080 \\
0.78\end{array}$ & $\begin{array}{c}1,373,080 \\
0.78\end{array}$ & $\begin{array}{c}1,373,080 \\
0.78\end{array}$ & $\begin{array}{c}1,373,080 \\
0.78\end{array}$ & $\begin{array}{c}1,373,080 \\
0.78\end{array}$ \\
\hline
\end{tabular}

This table reports the OLS regression results based on panel data from 2002 to 2015 for 10 Asian economies. Financial debt/assets is the ratio of the book value of total financial debt over the book value of total assets. FXdebt is the country-level share of FX debt defined as non-financial sector FX debt divided by total credit to the non-financial sector. Collateral is tangible fixed assets scaled by total assets. Profitability is the ROA ratio (i.e. EBIT/total assets). Size is the logarithm of total assets. Sales growth is the growth rate in sales. $t$-stats based on clustered standard errors at firm level are in parentheses.

${ }^{*} p<0.10,{ }^{* *} p<0.05,{ }^{* * *} p<0.01$.

One reason for this "wrong sign" interaction effect can be the role of government. Although we use lagged shares of FX debt and these shares are time-invariant mostly as shown before in Figure 2, it is still possible that governments of the commodity-exporting countries borrow 
less in response to an appreciation. We can subtract government bonds from FX bonds issued by the non-financial sector. Table 6 shows these results, and now all columns deliver the right sign on the interaction effect. Using the mean ratio of FX debt excluding government FX bonds to total debt (0.1191), a depreciation of 10 per cent or more decreases firm leverage by 0.1352 , whereas an appreciation of the same magnitude increases firm leverage only by 0.0108 , an order of magnitude difference.

Table 6: Benchmark Results: FX Debt—Excluding Government FX Bonds

\begin{tabular}{|c|c|c|c|c|c|c|}
\hline$\Delta e^{k}$ & $\begin{array}{c}(1) \\
k \geq+0 \%\end{array}$ & $\begin{array}{c}(2) \\
k \geq+5 \%\end{array}$ & $\begin{array}{c}(3) \\
k \geq+10 \%\end{array}$ & $\begin{array}{c}(4) \\
k \leq-0 \%\end{array}$ & $\begin{array}{c}(5) \\
k \leq-5 \%\end{array}$ & $k \leq-10 \%$ \\
\hline FXdebt $_{c, t-1} \times$ Dummy $\Delta e_{c, t}^{k}$ & $\begin{array}{l}-0.2061^{* * * *} \\
(-14.2)\end{array}$ & $\begin{array}{c}-0.3583^{* * *} \\
(-21.7)\end{array}$ & $\begin{array}{c}-1.1352^{* * *} \\
(-19.1)\end{array}$ & $\begin{array}{c}0.2061^{* * *} \\
(14.2)\end{array}$ & $\begin{array}{l}0.4327^{* * *} \\
(27.7)\end{array}$ & $\begin{array}{c}0.0908^{* * *} \\
(2.8)\end{array}$ \\
\hline FXdebt $_{c, t-1}$ & $\begin{array}{c}2.9789^{* * * *} \\
(82.2)\end{array}$ & $\begin{array}{c}2.9547^{* * *} \\
(83.4)\end{array}$ & $\begin{array}{c}2.9972^{* * * *} \\
(85.1)\end{array}$ & $\begin{array}{c}2.7714^{* * *} \\
(77.7)\end{array}$ & $\begin{array}{c}2.7816^{* * *} \\
(75.9)\end{array}$ & $\begin{array}{c}2.8315^{* * * *} \\
(78.4)\end{array}$ \\
\hline Dummy $\Delta e_{c, t}^{k}$ & $\begin{array}{c}0.0243^{* * * *} \\
(24.6)\end{array}$ & $\begin{array}{c}0.0478^{* * * *} \\
(43.9)\end{array}$ & $\begin{array}{c}0.0988^{* * * *} \\
(35.2)\end{array}$ & $\begin{array}{c}-0.0240^{* * *} \\
(-24.4)\end{array}$ & $\begin{array}{c}-0.0310^{* * *} \\
(-36.1)\end{array}$ & $\begin{array}{c}-0.0157^{* * * *} \\
(-8.6)\end{array}$ \\
\hline Profitability $_{i, j, c, t-1}$ & $\begin{array}{c}-0.0444^{* * *} \\
(-23.8)\end{array}$ & $\begin{array}{c}-0.0447^{* * *} \\
(-23.9)\end{array}$ & $\begin{array}{c}-0.0445^{* * *} \\
(-23.9)\end{array}$ & $\begin{array}{c}-0.0444^{* * * *} \\
(-23.8)\end{array}$ & $\begin{array}{c}-0.0444^{* * *} \\
(-23.8)\end{array}$ & $\begin{array}{c}-0.0445^{* * *} \\
(-23.8)\end{array}$ \\
\hline Collateral $_{i, j, c, t-1}$ & $\begin{array}{c}0.0670^{* * *} \\
(35.8)\end{array}$ & $\begin{array}{c}0.0673^{* * *} \\
(36.0)\end{array}$ & $\begin{array}{c}0.0688^{* * *} \\
(36.8)\end{array}$ & $\begin{array}{c}0.0670^{* * * *} \\
(35.8)\end{array}$ & $\begin{array}{c}0.0658^{* * *} \\
(35.2)\end{array}$ & $\begin{array}{c}0.0668^{* * * *} \\
(35.7)\end{array}$ \\
\hline Size $_{i, j, c, t-1}$ & $\begin{array}{l}0.0212^{* * * *} \\
(29.6)\end{array}$ & $\begin{array}{l}0.0209^{* * * *} \\
(29.3)\end{array}$ & $\begin{array}{l}0.0206^{* * *} \\
(28.9)\end{array}$ & $\begin{array}{l}0.0212^{* * *} \\
(29.6)\end{array}$ & $\begin{array}{l}0.0208^{* * *} \\
(29.1)\end{array}$ & $\begin{array}{l}0.0216^{* * *} \\
(30.3)\end{array}$ \\
\hline Sales growth ${ }_{i, j, c, t-1}$ & $\begin{array}{c}-0.0008^{* * * *} \\
(-2.9)\end{array}$ & $\begin{array}{c}-0.0008^{* * *} \\
(-2.9)\end{array}$ & $\begin{array}{c}-0.0009^{* * *} \\
(-3.1)\end{array}$ & $\begin{array}{c}-0.0008^{* * * *} \\
(-2.9)\end{array}$ & $\begin{array}{c}-0.0010^{* * * *} \\
(-3.3)\end{array}$ & $\begin{array}{c}-0.0009 * * * \\
(-3.2)\end{array}$ \\
\hline Firm FE & Yes & Yes & Yes & Yes & Yes & Yes \\
\hline Country FE & Yes & Yes & Yes & Yes & Yes & Yes \\
\hline Industry-Year FE & Yes & Yes & Yes & Yes & Yes & Yes \\
\hline $\begin{array}{l}\text { Observations } \\
R^{2}\end{array}$ & $\begin{array}{l}1,373,080 \\
0.78\end{array}$ & $\begin{array}{l}1,373,080 \\
0.78\end{array}$ & $\begin{array}{l}1,373,080 \\
0.78\end{array}$ & $\begin{array}{c}1,373,080 \\
0.78\end{array}$ & $\begin{array}{l}1,373,080 \\
0.78\end{array}$ & $\begin{array}{c}1,373,080 \\
0.78\end{array}$ \\
\hline
\end{tabular}

This tables uses FX debt of the non-financial sector after excluding FX government bonds. See notes to the previous table for the definitions of other variables.

${ }^{*} p<0.10,{ }^{* *} p<0.05,{ }^{* * *} p<0.01$.

Next, we consider FX loans and FX bonds separately to see which type of FX debt drives the results. Table 7 shows that firms in a country where the share of FX loans in the total non-financial sector debt is higher, tend to have higher (lower) leverage when the country experiences an appreciation (depreciation). Given much larger magnitudes in this table, it is clear that our results are driven by FX loan exposures. In particular, when we use the mean ratio of FX loans to total debt (0.0996), the effect of a 10 percent or more depreciation is a decline in leverage of 0.1517 and the effect of a 10 percent or more appreciation is an increase in leverage of 0.0265 . Given that the mean firm leverage is 0.16 , a 10 percent or more depreciation represents a very large change in leverage, equivalent to the mean. An appreciation of 10 percent or more also represents a 20 percent increase in leverage over its sample mean. 
Table 7: Benchmark Results: FX Loans

\begin{tabular}{|c|c|c|c|c|c|c|}
\hline$\Delta e^{k}$ & $\begin{array}{c}(1) \\
k \geq+0 \%\end{array}$ & $\begin{array}{c}(2) \\
k \geq+5 \%\end{array}$ & $\begin{array}{c}(3) \\
k \geq+10 \%\end{array}$ & $\begin{array}{c}(4) \\
k \leq-0 \%\end{array}$ & $\begin{array}{c}(5) \\
k \leq-5 \%\end{array}$ & $\begin{array}{c}(6) \\
k \leq-10 \%\end{array}$ \\
\hline FXloan $_{c, t-1} \times$ Dummy $\Delta e_{c, t}^{k}$ & $\begin{array}{c}-0.1681^{* * *} \\
(-9.8)\end{array}$ & $\begin{array}{c}-0.5514^{* * * *} \\
(-26.8)\end{array}$ & $\begin{array}{c}-1.5236^{* * *} \\
(-23.7)\end{array}$ & $\begin{array}{c}0.1701^{* * * *} \\
(9.9)\end{array}$ & $\begin{array}{c}0.5065^{* * *} \\
(24.9)\end{array}$ & $\begin{array}{c}0.2665^{* * *} \\
(7.4)\end{array}$ \\
\hline FXloan $_{c, t-1}$ & $\begin{array}{c}3.2094^{* * *} \\
(82.6)\end{array}$ & $\begin{array}{c}3.2292^{* * * *} \\
(86.4)\end{array}$ & $\begin{array}{c}3.2194^{* * *} \\
(87.0)\end{array}$ & $\begin{array}{c}3.0413^{* * *} \\
(81.9)\end{array}$ & $\begin{array}{c}3.0571^{* * *} \\
(79.6)\end{array}$ & $\begin{array}{c}3.0670^{* * *} \\
(81.9)\end{array}$ \\
\hline Dummy $\Delta e_{c, t}^{k}$ & $\begin{array}{c}0.0148^{* * *} \\
(16.4)\end{array}$ & $\begin{array}{c}0.0443^{* * *} \\
(44.3)\end{array}$ & $\begin{array}{c}0.0897^{* * *} \\
(39.1)\end{array}$ & $\begin{array}{c}-0.0149^{* * *} \\
(-16.6)\end{array}$ & $\begin{array}{c}-0.0290^{* * *} \\
(-34.0)\end{array}$ & $\begin{array}{c}-0.0234^{* * *} \\
(-14.9)\end{array}$ \\
\hline Profitability $i, j, c, t-1$ & $\begin{array}{c}-0.0445^{* * *} \\
(-23.8)\end{array}$ & $\begin{array}{c}-0.0447^{* * * *} \\
(-24.0)\end{array}$ & $\begin{array}{c}-0.0445^{* * *} \\
(-23.9)\end{array}$ & $\begin{array}{c}-0.0445^{* * *} \\
(-23.8)\end{array}$ & $\begin{array}{c}-0.0445^{* * *} \\
(-23.8)\end{array}$ & $\begin{array}{c}-0.0446^{* * *} \\
(-23.9)\end{array}$ \\
\hline Collateral $_{i, j, c, t-1}$ & $\begin{array}{c}0.0678^{* * *} \\
(36.3)\end{array}$ & $\begin{array}{c}0.0678^{* * * *} \\
(36.3)\end{array}$ & $\begin{array}{c}0.0695^{* * *} \\
(37.2)\end{array}$ & $\begin{array}{c}0.0678^{* * *} \\
(36.3)\end{array}$ & $\begin{array}{c}0.0666^{* * *} \\
(35.6)\end{array}$ & $\begin{array}{c}0.0673^{* * *} \\
(36.0)\end{array}$ \\
\hline $\operatorname{Size}_{i, j, c, t-1}$ & $\begin{array}{c}0.0219^{* * *} \\
(30.6)\end{array}$ & $\begin{array}{c}0.0216^{* * *} \\
(30.2)\end{array}$ & $\begin{array}{c}0.0213^{* * *} \\
(29.8)\end{array}$ & $\begin{array}{c}0.0219^{* * *} \\
(30.6)\end{array}$ & $\begin{array}{c}0.0215^{* * *} \\
(30.0)\end{array}$ & $\begin{array}{c}0.0222^{* * *} \\
(31.1)\end{array}$ \\
\hline Sales growth ${ }_{i, j, c, t-1}$ & $\begin{array}{c}-0.0008^{* * * *} \\
(-2.8)\end{array}$ & $\begin{array}{c}-0.0007^{* *} \\
(-2.6)\end{array}$ & $\begin{array}{c}-0.0009^{* * * *} \\
(-3.1)\end{array}$ & $\begin{array}{c}-0.0008^{* * *} \\
(-2.8)\end{array}$ & $\begin{array}{c}-0.0010^{* * *} \\
(-3.3)\end{array}$ & $\begin{array}{c}-0.0009^{* * * *} \\
(-3.2)\end{array}$ \\
\hline Firm FE & Yes & Yes & Yes & Yes & Yes & Yes \\
\hline Country FE & Yes & Yes & Yes & Yes & Yes & Yes \\
\hline Industry-Year FE & Yes & Yes & Yes & Yes & Yes & Yes \\
\hline Observations & $1,373,080$ & $1,373,080$ & $1,373,080$ & $1,373,080$ & $1,373,080$ & $1,373,080$ \\
\hline$R^{2}$ & 0.78 & 0.78 & 0.78 & 0.78 & 0.78 & 0.78 \\
\hline
\end{tabular}

This tables uses FX loans only when defining the share of FX debt, that is this share is equal to FX loans/total credit to the nonfinancial sector. See notes to the previous tables for all other variables.

${ }^{*} p<0.10,{ }^{* *} p<0.05,{ }^{* * *} p<0.01$.

Finally, our benchmark result is robust to using continuous changes in exchange rates as shown in Table 8. As shown with the negative coefficient, the higher the depreciation, the lower the leverage. The results using continuous changes in exchange rates for specifications in Tables 6 and 7 are also similar.

\subsection{Firm-Level FX Debt: Non-Financial Sector Proxy Approach}

A threat to our identification is the omitted country-year shocks, policies and other factors. To be able to control for these, in this section we will include country $\times$ year fixed effects. Given the fact that our main variable of interest is at the country-time level (interaction of exchange rate movements with FX debt), we will redefine FX debt to be at the firm level.

To do this, we proceed with two approaches. First, we assume that each firm's share of FX debt is equal to the aggregate non-financial sector share (after excluding government FX debt). Then we apply this share to each firm's total debt to get the firm-level FX debt. The appendix explains in detail how we calculate firm-level FX debt. By construction, larger firms will have more debt and hence more FX debt. Thus, it is important to control for time-varying firm size in the regressions. We use firm-level FX debt as a dummy in the regressions, where we create 
Table 8: Benchmark Results: Continuous Changes in the Exchange Rate

\begin{tabular}{|c|c|}
\hline & $(1)$ \\
\hline $\mathrm{FXdebt}_{c, t-1} \times \Delta e_{c, t}$ & $\begin{array}{c}-0.2809^{* * *} \\
(-3.8)\end{array}$ \\
\hline FXdebt $t_{c, t-1}$ & $\begin{array}{c}2.4462^{* * * *} \\
(68.8)\end{array}$ \\
\hline$\Delta e_{c, t}$ & $\begin{array}{c}0.1237^{* * *} \\
(30.9)\end{array}$ \\
\hline Profitability $_{i, j, c, t-1}$ & $\begin{array}{c}-0.0440^{* * * *} \\
(-23.6)\end{array}$ \\
\hline Collateral $_{i, j, c, t-1}$ & $\begin{array}{c}0.0654^{* * * *} \\
(34.9)\end{array}$ \\
\hline Size $_{i, j, c, t-1}$ & $\begin{array}{c}0.0196^{* * *} \\
(27.3)\end{array}$ \\
\hline Sales growth $\mathrm{th}_{i, j, c, t-1}$ & $\begin{array}{c}-0.0011^{* * *} \\
(-3.9)\end{array}$ \\
\hline Firm FE & Yes \\
\hline Country FE & Yes \\
\hline Industry-Year FE & Yes \\
\hline Observations & $1,373,080$ \\
\hline$R^{2}$ & 0.7813 \\
\hline
\end{tabular}

This table reports the regression results using the continuous exchange rate change $\Delta e_{c, t}$ which is defined as the change in the exchange rate as local currency/USD in country $c$ from year $t-1$ to year $t$. See notes to the previous tables for all other variables.

${ }^{*} p<0.10,{ }^{* *} p<0.05,{ }^{* * *} p<0.01$.

a time-invariant dummy variable for firm-level FX debt exposure, FXdebt ${ }_{i}$, that takes value 1 when the average value of FX debt of a firm is higher than the respective value of the median firm in the same country, and zero otherwise. For our second approach, we use actual firmlevel FX debt data from four countries, which will also allow us to check the validity of our proxy approach.

For our first approach, we interact the two dummies, that is, firm-level FX debt and dummy for appreciations/depreciations. This interaction term corresponds to a "Difference-in-Differences" interpretation of the relative effect of an appreciation (or depreciation) on firms with different degrees of FX debt exposure. We also interact all the firm-level controls with the appreciation/depreciation dummy, to make sure that our main variable of interest is not a proxy for these effects. We include firm, industry-year and country-year fixed effects. The firm fixed effects help to control the unobserved firm-level time-invariant heterogeneity and help us to identify from within variation as before. The industry-year and country-year fixed effects con- 
trol all shocks, policy changes and unobserved time-varying heterogeneity at the industry and country levels, respectively. The dummy for appreciation (or depreciation) will be absorbed by the country-year fixed effects and the dummy for the firm-level FX debt will be absorbed by the firm fixed effects.

Our micro-level specification (as we now use firm-level FX debt instead of country-level) is as follows:

$$
\begin{aligned}
& \text { Leverage }_{i, j, c, t}=\beta \cdot \mathrm{FXdebt}_{i} \times \text { Dummy } \Delta e_{c, t}^{k}+\theta_{1} \cdot X_{i, c, t-1}+\theta_{2} \cdot X_{i, c, t-1} \times \operatorname{Dummy} e_{c, t}^{k} \\
& +\alpha_{i}+\gamma_{c, t}+\phi_{j, t}+\varepsilon_{i, j, c, t}
\end{aligned}
$$

where Leverage $e_{i, j, c, t}$ and $X_{i, c, t-1}$ are the same as in equation (1). $\alpha_{i}$ captures the firm fixed effects, while $\gamma_{c, t}$ and $\phi_{j, t}$ the country-year and industry-year fixed effects, respectively. We again estimate the regression model using the OLS method with robust standard errors clustered at the firm level. ${ }^{12}$ A dynamic system GMM estimation provided similar results. FXdebt is obtained for each firm as explained above with the proxy approach.

Table 9 reports the results for depreciations and appreciations more than 10 per cent in columns (1) and (2), respectively. Our results are similar to the results before, though with smaller coefficients. These smaller coefficients show the importance of country $\times$ year fixed effects, that is the role of other policies and country-level shocks driving the relation between exchange rate changes and firm leverage, leading to higher coefficients. The interaction of other firm-level controls with exchange rate movements shows the importance of controlling these effects as certain firms behave in the opposite way. For example, larger firms do not increase leverage with appreciations. These results show the importance of using a representative set of firms and not only relying on large listed firms for inference on the effects of exchange rate changes on firm leverage. Our results are again robust to using continuous changes in exchange rates as shown in Table 10.

\subsection{Other Robustness}

We provide further robustness on our proxy approach to firm-level FX debt to see if results can be driven by other factors.

\footnotetext{
${ }^{12}$ The results are robust to clustering standard errors at the country level.
} 


\section{Table 9: Firm-Level FX Debt based on Proxy Approach}

Dependent variable: Financial debt/assets $s_{i, j, c, t}$

\begin{tabular}{|c|c|c|}
\hline$\Delta e^{k}$ & $\begin{array}{c}(1) \\
k \geq+10 \%\end{array}$ & $\begin{array}{c}(2) \\
k \leq-10 \%\end{array}$ \\
\hline $\mathrm{FXdebt}_{i} \times$ Dummy $\Delta e_{c, t}^{k}$ & $\begin{array}{c}-0.0058^{* * *} \\
(-3.7)\end{array}$ & $\begin{array}{l}0.0550^{* * *} \\
(26.8)\end{array}$ \\
\hline Profitability $_{i, j, c, t-1}$ & $\begin{array}{c}-0.0442^{* * *} \\
(-23.9)\end{array}$ & $\begin{array}{c}-0.0427^{* * *} \\
(-23.2)\end{array}$ \\
\hline Profitability $_{i, j, c, t-1} \times$ Dummy $\Delta e_{c, t}^{k}$ & $\begin{array}{l}-0.0235^{* * *} \\
(-2.7)\end{array}$ & $\begin{array}{c}-0.0151^{* * *} \\
(-2.7)\end{array}$ \\
\hline Collateral $_{i, j, c, t-1}$ & $\begin{array}{l}0.0690^{* * *} \\
(37.1)\end{array}$ & $\begin{array}{l}0.0704^{* * *} \\
(38.1)\end{array}$ \\
\hline 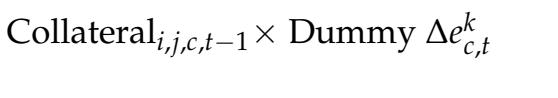 & $\begin{array}{l}0.0364^{* * *} \\
(12.7)\end{array}$ & $\begin{array}{c}-0.0114^{* * * *} \\
(-3.6)\end{array}$ \\
\hline $\operatorname{Size}_{i, j, c, t-1}$ & $\begin{array}{l}0.0202^{* * *} \\
(28.2)\end{array}$ & $\begin{array}{l}0.0212^{* * *} \\
(29.5)\end{array}$ \\
\hline $\operatorname{Size}_{i, j, c, t-1} \times$ Dummy $\Delta e_{c, t}^{k}$ & $\begin{array}{l}0.0040^{* * *} \\
\quad(6.9)\end{array}$ & $\begin{array}{c}-0.0106^{* * *} \\
(-19.7)\end{array}$ \\
\hline Sales growth $_{i, j, c, t-1}$ & $\begin{array}{c}-0.0006^{*} \\
(-1.9)\end{array}$ & $\begin{array}{c}-0.0005^{*} \\
(-1.8)\end{array}$ \\
\hline Sales growth $_{i, j, c, t-1} \times$ Dummy $\Delta e_{c, t}^{k}$ & $\begin{array}{c}0.0002 \\
(0.2)\end{array}$ & $\begin{array}{c}-0.0023 \\
(-1.4)\end{array}$ \\
\hline Firm FE & Yes & Yes \\
\hline Country-Year FE & Yes & Yes \\
\hline Industry-Year FE & Yes & Yes \\
\hline $\begin{array}{l}\text { Observations } \\
R^{2}\end{array}$ & $\begin{array}{l}1,372,970 \\
0.79\end{array}$ & $\begin{array}{l}1,372,970 \\
0.79\end{array}$ \\
\hline
\end{tabular}

FXdebt is a dummy that equals 1 if a firm's average FX debt during the sample period is higher than the country's sample median, and equals 0 otherwise. See notes to the previous tables for all other variables. The standard errors are clustered at the firm level. $t$-statistics are reported in parentheses. ${ }^{*} p<0.10,{ }^{* *} p<0.05,{ }^{* * *} p<0.01$. 
Table 10: Firm-Level FX Debt based on Proxy Approach: Continuous Changes in the Exchange Rate

\begin{tabular}{|c|c|}
\hline & (1) \\
\hline $\mathrm{FXdebt}_{i} \times \Delta e_{c, t}$ & $\begin{array}{c}-0.0985^{* * *} \\
(-21.2)\end{array}$ \\
\hline Profitability $_{i, j, c, t-1}$ & $\begin{array}{c}-0.0456^{* * *} \\
(-24.4)\end{array}$ \\
\hline Profitability $_{i, j, c, t-1} \times \Delta e_{c, t}$ & $\begin{array}{c}-0.0691^{* * *} \\
(-3.3)\end{array}$ \\
\hline Collateral $_{i, j, c, t-1}$ & $\begin{array}{c}0.0703^{* * *} \\
(37.9)\end{array}$ \\
\hline Collateral $_{i, j, c, t-1} \times \Delta e_{c, t}$ & $\begin{array}{c}0.0260^{* * *} \\
(3.1)\end{array}$ \\
\hline Size $_{i, j, c, t-1}$ & $\begin{array}{c}0.0207^{* * *} \\
(28.8)\end{array}$ \\
\hline $\operatorname{Size}_{i, j, c, t-1} \times \Delta e_{c, t}$ & $\begin{array}{c}0.0173^{* * *} \\
(10.4)\end{array}$ \\
\hline Sales growth ${ }_{i, j, c, t-1}$ & $\begin{array}{c}-0.0006^{* *} \\
(-2.0)\end{array}$ \\
\hline Sales growth ${ }_{i, j, c, t-1} \times \Delta e_{c, t}$ & $\begin{array}{c}0.0045 \\
(1.3)\end{array}$ \\
\hline Firm FE & Yes \\
\hline Country-Year FE & Yes \\
\hline Industry-Year FE & Yes \\
\hline Observations & $1,372,970$ \\
\hline$R^{2}$ & 0.79 \\
\hline
\end{tabular}

This table reports the regression results using the continuous exchange rate change $\Delta e_{c, t}$ which is defined as the change in the exchange rate as local currency/USD in country $c$ from year $t-1$ to year $t$. See notes to the previous tables for all other variables. The standard errors are clustered at the firm level. $t$-statistics are reported in parentheses.

${ }^{*} p<0.10,{ }^{* *} p<0.05,{ }^{* * *} p<0.01$. 
First, we conduct a placebo test to see if there is still any effect when the exchange rate changes minimally. We redefine our appreciation and depreciation dummies for very little changes in the exchange rate, where we limit the appreciations or depreciations to less than 1 per cent. We also used alternative thresholds such as no more than 2 per cent for appreciation or depreciation, and obtained similar results. The results are reported in Table 11. We have run this exercise as an event analysis using only those years with limited exchange rate changes, which is why we lose observations. We show only the coefficient of interest on the interaction of firm-level FX debt and the change in the exchange rate dummy. Clearly this is insignificant. This exercise shows the importance of the size of exchange rate movements to realize the effects on firm leverage. It also shows that our firm-level FX debt proxy does not capture other factors creating a spurious relation between this firm-level dummy and firm-level leverage. The exchange rate shock clearly matters for the relation between firm-level leverage and FX debt.

Table 11: Placebo Test

Dependent variable: Financial debt/assets $s_{i, j, c, t}$

\begin{tabular}{lcccc}
\hline & $(1)$ & $(2)$ & $(3)$ & $(4)$ \\
$\Delta e^{k}$ & $1 \% \geq k>0 \%$ & $1 \% \geq k>0 \%$ & $-1 \% \leq k<-0 \%$ & $-1 \% \leq k<-0 \%$ \\
\hline FXdebt ${ }_{i} \times$ Dummy $\Delta e_{c, t}^{k}$ & -0.0629 & -0.0421 & $-0.0049^{*}$ & $-0.0049^{*}$ \\
& $(-1.1)$ & $(-0.9)$ & $(-8.9)$ & $(-6.5)$ \\
\hline Firm Controls & Yes & Yes & Yes & Yes \\
Firm Controls $\times$ Dummy $\Delta e_{c, t}^{k}$ & No & Yes & No & Yes \\
Firm FE & Yes & Yes & Yes & Yes \\
Country-Year FE & Yes & Yes & Yes & Yes \\
Industry-Year FE & Yes & Yes & Yes & Yes \\
\hline Observations & 144,372 & 144,372 & 249,693 & 249,693 \\
$R^{2}$ & 0.84 & 0.84 & 0.85 & 0.85 \\
\hline
\end{tabular}

See notes to the previous tables for all other variables. $t$-statistics are reported in parentheses.

${ }^{*} p<0.10,{ }^{* *} p<0.05,{ }^{* * *} p<0.01$.

We further investigate the role of firms in the non-tradeable sector. Since firms in the tradeable sector have more capacity to generate revenues in FX, their borrowing in FX could be hedged by cash flows. The balance sheet channel therefore should work stronger for firms in the non-tradeable sector because they are likely to be more sensitive to exchange rate shocks. As commonly classified in the literature, the tradeable sector includes agriculture, mining and manufacturing industries, while the non-tradeable sector includes construction, transportation, communication, utilities, wholesale/retail trade, and services. Therefore, we split the firms to see the different effects on firms in the tradeable and non-tradeable sectors. 
As conjectured, Table 12 shows that the effects of depreciations are significant in the nontradeable sector while insignificant in the tradeable sector. ${ }^{13}$ The effects of appreciations are significant in both sectors but stronger in the non-tradeable sector, as the coefficient is twice the size of the coefficient for the tradeable sector.

Table 12: Tradeable and Non-Tradeable Sector Firms

Dependent variable: Financial debt/assets $s_{i, j, c, t}$

\begin{tabular}{lcccc}
\hline & Tradeable & $\begin{array}{c}\text { Non- } \\
\text { tradeable }\end{array}$ & Tradeable & $\begin{array}{c}\text { Non- } \\
\text { tradeable }\end{array}$ \\
\hline$\Delta e^{k}$ & $k \geq+10 \%$ & $k \geq+10 \%$ & $k \leq-10 \%$ & $k \leq-10 \%$ \\
\hline FXdebt ${ }_{i} \times$ Dummy $\Delta e_{c, t}^{k}$ & -0.0037 & $-0.0048^{* *}$ & $0.0341^{* * *}$ & $0.0643^{* * *}$ \\
& $(-1.5)$ & $(-2.3)$ & $(10.8)$ & $(22.4)$ \\
\hline Firm Controls & Yes & Yes & Yes & Yes \\
Firm Controls $\times$ Dummy $\Delta e_{c, t}^{k}$ & Yes & Yes & Yes & Yes \\
Firm FE & Yes & Yes & Yes & Yes \\
Country-Year FE & Yes & Yes & Yes & Yes \\
Industry-Year FE & Yes & Yes & Yes & Yes \\
\hline Observations & 768,318 & 547,414 & 768,318 & 547,414 \\
$R^{2}$ & 0.82 & 0.75 & 0.82 & 0.76 \\
\hline
\end{tabular}

See notes to the previous tables for all other variables.t-statistics are reported in parentheses.

${ }^{*} p<0.10,{ }^{* *} p<0.05,{ }^{* * *} p<0.01$.

Next, we test the role of maturity by looking at the effect of currency appreciations (depreciations) on short-term and long-term debt-based leverage. We again focus on the case of more than 10 percent depreciations and appreciations. Table 13 shows that the main effects are due to changes in long-term debt-based leverage.

In fact, for depreciations, the effect of FX debt on short-term debt is opposite: during depreciations more than 10 per cent, firms with higher FX debt increase short-term based leverage and decrease long-term based leverage. This is consistent with a roll-over crisis during large sudden stop events and financial crises where firms try to borrow short term, if they can, to roll over their maturing debt. Clearly firms with FX debt are more stressed during such events and hence they do this more, while reducing the long-term leverage and strengthening their balance sheet to be able to borrow short term. The work of Albuquerque and Hopenhayn (2004) predicts exactly this relation for a closed economy for local currency debt for distressed

\footnotetext{
${ }^{13}$ This result is in line with Bleakley and Cowan (2008) who find no effect of balance sheet mismatch on investment of exporters.
} 
Table 13: The Role of Debt Maturity

\begin{tabular}{lcccc} 
Dependent variable. & LT & ST & LT & ST \\
\hline \multirow{2}{*}{$\Delta e^{k}$} & $(1)$ & $(2)$ & $(3)$ & $(4)$ \\
\hline FXdebt ${ }_{i} \times$ Dummy $\Delta e_{c, t}^{k}$ & $k \geq+10 \%$ & $k \geq+10 \%$ & $k \leq-10 \%$ & $k \leq-10 \%$ \\
& $-0.0099^{* * *}$ & $0.0038^{* * *}$ & $0.0501^{* * *}$ & $0.0052^{* * *}$ \\
& $(-7.1)$ & $(3.2)$ & $(27.4)$ & $(5.9)$ \\
\hline Firm Controls & Yes & Yes & Yes & Yes \\
Firm Controls $\times$ Dummy $\Delta e_{c, t}^{k}$ & Yes & Yes & Yes & Yes \\
Firm FE & Yes & Yes & Yes & Yes \\
Country-Year FE & Yes & Yes & Yes & Yes \\
Industry-Year FE & Yes & Yes & Yes & Yes \\
\hline Observations & $1,372,970$ & $1,372,970$ & $1,372,970$ & $1,372,970$ \\
$R^{2}$ & 0.74 & 0.75 & 0.74 & 0.75 \\
\hline
\end{tabular}

See notes to the previous tables for all other variables. $t$-statistics are reported in parentheses.

${ }^{1} \mathrm{LT}$ and ST are short for LT debt/assets $i_{i, j, c, t}$ and ST debt/assets ${ }_{i, j, c, t}$, respectively. LT debt/assets is the ratio of the book value of long-term (remaining maturity more than 1 year) financial debt over the book value of total assets at the end of fiscal year $t$. ST debt/assets is the ratio of the book value of short-term (remaining maturity equal to or less than 1 year) financial debt over the book value of total assets at the end of fiscal year $t$.

${ }^{*} p<0.10,{ }^{* *} p<0.05,{ }^{* * *} p<0.01$.

firms. This roll-over effect is not relevant for appreciations of course and hence the effects of appreciations are in the same direction but stronger in magnitude for the long-term debt-based leverage, consistent with appreciations making balance sheets stronger for firms with FX debt.

\subsection{Firm-Level FX Debt Share: Data for Select Countries}

One may be concerned that the country-level non-financial sector FX debt share applied to all firms to back out the firm-level FX debt is not a good approach. Therefore, we proceed with our second approach of using actual firm-level data on firm-level FX debt shares in their total debt. ${ }^{14}$ We have such firm-level data only for four countries: Korea, Argentina, Mexico and Colombia. Also the data are only for listed firms and hence these samples will be different from our benchmark sample of 10 economies that covers private firms.

The only country common to both data sets, that is our ORBIS data and the new firm-level FX debt data we obtained for the four countries, is Korea. To illustrate that our proxy approach does not capture anything different in terms of dynamics, we will use Korea data and compare the aggregate non-financial sector FX debt share of Korea in our data for 1994 to 1999 to the

\footnotetext{
${ }^{14}$ We thank Kim, Tesar and Zhang (2015) for sharing their firm-level data for Korea and Kalemli-Ozcan, Kamil and Villegas-Sanchez (2014) for sharing their firm-level data for Argentina, Brazil and Mexico.
} 
"aggregated" firm-level data we got from Kim, Tesar and Zhang (2015) for those years. ${ }^{15}$ As shown in Figure 4, they follow similar patterns. ${ }^{16}$ In 1997, the year of the Asian financial crisis, the increase in the share of FX debt in total debt is larger in the aggregate than the average firm in the sample of Korean listed firms, which again shows the importance of using a representative set of firms. The FX share increases as local currency debt collapses during these type of sudden stop crises and listed firms might have more access to local currency debt markets during such events. Nevertheless, the time variation in our aggregate BIS data and in Korea KIS firm data seems to be similar and this is important as all our regressions are identified from such dynamic (within) variation.

It is worth noting the differences in the variables and breadth of the two different firm samples for Korea. Notice that our data are for the later period and hence firms in the two datasets on Korea cannot be matched. Kim, Tesar and Zhang (2015) use data from Korea Information Service, Inc. (KIS) which includes FX debt information for a set of select listed Korean firms. They construct their FX exposure variables as the ratio of FX debt to net worth. The coverage of firms between the two samples is quite different. Our ORBIS-based sample of Korean firms includes 151,684 firms, the majority of which are small, unlisted firms and most of which have not been rated by rating agencies. By contrast, the KIS is a rating agency and thus the KIS data-based sample of 6,987 firms are mostly relatively large, rated domestic bond issuers. In Kim, Tesar and Zhang (2015), the sample only includes firms with total assets no less than 7 billion Korean won. In this sample, the median of total assets and total liabilities are around 13 billion won and 9 billion won, respectively. By contrast, in our ORBIS-based sample, the median of total assets and total liabilities are around 3 billion won and 1.5 billion won, respectively. Clearly we have a much more representative sample in terms of firm size.

\footnotetext{
${ }^{15}$ Our firm level data for Korea is for later years.

${ }^{16}$ To compare with country-level FX debt shares, we calculate Korean firms' average debt-to-liability ratio based on our ORBIS sample, which is around 0.6 and then estimate the FX debt-to-total debt ratio by dividing the foreign debt-to-liability ratio by 0.6 . This is because Korean data only reports total liability and not total debt, which is what we use due to the existence of non-financial obligations in total liability item as argued in our data section.
} 


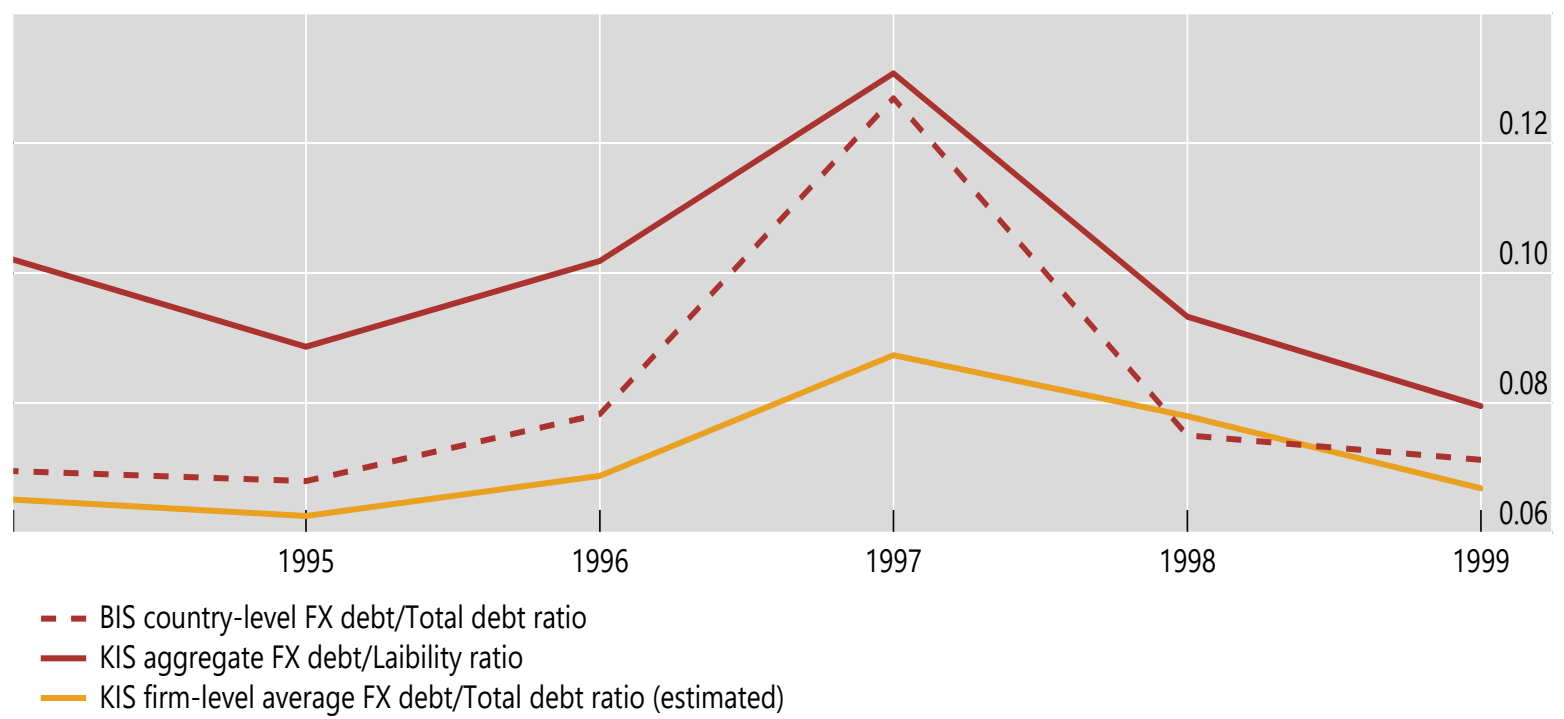

Figure 4: Comparison of FX Debt Share

This figure shows the simple average of FX debt shares of Korean firms using the KIS sample and the ratio of aggregate FX debt to aggregate liabilities using the KIS sample, compared with the BIS country-level FX debt share. Data source: BIS, KIS.

Next we use firm-level FX debt data for Korea during 1994 to 1999 in regressions to see if we obtain similar results. Since we do not have the detailed firm-level controls for Korea, we run the following regression using the firm-level data available for Korea:

$$
\text { Leverage }_{i, j, c, t}=\beta \cdot \text { FXdebt share }_{i} \times \text { Dummy } \Delta e_{c, t}^{k}+\alpha_{i}+\phi_{j, t}+\varepsilon_{i, j, c, t}
$$

where FXdebt share $i$ takes value 1 when the average FX debt share of a firm is higher than the respective value of the median firm, and zero otherwise. Leverage $e_{i, j, c, t}$ is defined as the liability-to-asset ratio due to no available data on total debt in the current KIS dataset. $\alpha_{i}$ captures the firm fixed effects, while $\phi_{j, t}$ industry-year fixed effects.

Table 14 reports the results for depreciations and appreciations more than 0,5 or 10 per cent in columns (1) to (6), respectively. We also add one more result using continuous exchange rate changes in the interaction term to show the robustness in column (7). Our results are similar to the results in benchmark Table 9 in terms of the sign and significance of the interaction term of high FX debt dummy with exchange rate movements. 
Table 14: Firm-Level FX Debt: Evidence from Korea

Dependent variable: Liability/assets ${ }_{i, j, c, t}$

\begin{tabular}{|c|c|c|c|c|c|c|c|}
\hline & (1) & (2) & (3) & (4) & (5) & (6) & (7) \\
\hline$\Delta e^{k}$ & $k \geq+0 \%$ & $k \geq+5 \%$ & $k \geq+10 \%$ & $k \leq-0 \%$ & $k \leq-5 \%$ & $k \leq-10 \%$ & $k$ \\
\hline FXdebt share $_{i} \times$ Dummy $\Delta e_{c, t}^{k}$ & $-0.013^{* * *}$ & $-0.013^{* * *}$ & $-0.020^{* * *}$ & $0.013^{* * *}$ & $0.015^{* * *}$ & $0.039 * * *$ & $-0.038^{* * *}$ \\
\hline$\left(\times \Delta e_{c, t}\right.$ for col $\left.(7)\right)$ & $(-4.4)$ & $(-4.4)$ & $(-7.0)$ & $(4.4)$ & $(3.8)$ & $(12.3)$ & $(-9.3)$ \\
\hline Firm FE & Yes & Yes & Yes & Yes & Yes & Yes & Yes \\
\hline Industry-Year FE & Yes & Yes & Yes & Yes & Yes & Yes & Yes \\
\hline Observations & 17,033 & 17,033 & 17,033 & 17,033 & 17,033 & 17,033 & 17,033 \\
\hline$R^{2}$ & 0.83 & 0.83 & 0.83 & 0.83 & 0.83 & 0.83 & 0.83 \\
\hline
\end{tabular}

FXdebt share $i$ is a dummy that equals 1 if a firm's average FX debt scaled by total liability during the sample period is higher than the country's sample median, and equals 0 otherwise. See notes to the previous tables for all other variables. The standard errors are clustered at the firm level. $t$-statistics are reported in parentheses.

${ }^{*} p<0.10,{ }^{* *} p<0.05,{ }^{* * *} p<0.01$.

To further support our evidence, we bring in firm-level data on FX debt shares from three other countries, Argentina, Mexico and Brazil, during 1990-2005. We also control other firmlevel controls in these regressions. As these countries went through very severe crises during this period, for large depreciations of columns (1) and (3) we define a threshold of the 90th percentile of changes in the exchange rate between local currency and US dollar in the data sample, which is around a $24 \%$ depreciation of local currency. The dummy for large appreciation used in columns (2) and (4) is defined by the threshold of the 1st percentile of change in the exchange rate which is a $16 \%$ appreciation of local currency.

The detailed results are reported in Table 15. These results are consistent with our previous results for depreciations, but for appreciations we only find an effect for exporters. Column (4) shows that exporters defined as high exporters (10 per cent of revenues are from exports) are the ones who significantly increase their leverage with appreciations.

\subsection{The Role of Exchange Rate Policies}

As we have argued before, the literature on asymmetric affects of depreciations and appreciations provides a rationale for the use of foreign exchange intervention (FXI) policies in order to limit appreciations (lean against the wind) so that risk-taking behavior of firms will be limited and firm leverage will be lower. A parallel literature talks about the costs of reserve accumulation and FXI policies during depreciations in terms of moral hazard where firms expecting FXI during depreciations, will increase leverage during appreciations in any case. 
Table 15: Firm-Level FX Debt: Evidence from Argentina, Mexico and Brazil Dependent variable: Liability/assets $i_{i, j, c, t}$

\begin{tabular}{|c|c|c|c|c|}
\hline & \multicolumn{2}{|c|}{ All firms } & \multicolumn{2}{|c|}{ High exporters } \\
\hline$\Delta e^{k}$ & $\begin{array}{c}(1) \\
k \geq \\
\text { 90th percentile }\end{array}$ & $\begin{array}{c}(2) \\
k \leq \\
\text { 1st percentile }\end{array}$ & $\begin{array}{c}(3) \\
k \geq \\
\text { 90th percentile }\end{array}$ & $\begin{array}{c}(4) \\
k \leq \\
\text { 1st percentile }\end{array}$ \\
\hline $\mathrm{FXdebt}_{i} \times$ Dummy $\Delta e_{c, t}^{k}$ & $\begin{array}{c}-0.017^{* *} \\
(0.01)\end{array}$ & $\begin{array}{l}0.020 \\
(0.02)\end{array}$ & $\begin{array}{c}-0.031^{* *} \\
(0.01)\end{array}$ & $\begin{array}{l}0.060^{* *} \\
(0.03)\end{array}$ \\
\hline $\begin{array}{l}\text { Firm FE } \\
\text { Firm Controls } \\
\text { Country-Year FE } \\
\text { Industry-Year FE }\end{array}$ & $\begin{array}{l}\text { Yes } \\
\text { Yes } \\
\text { Yes } \\
\text { Yes }\end{array}$ & $\begin{array}{l}\text { Yes } \\
\text { Yes } \\
\text { Yes } \\
\text { Yes }\end{array}$ & $\begin{array}{l}\text { Yes } \\
\text { Yes } \\
\text { Yes } \\
\text { Yes }\end{array}$ & $\begin{array}{l}\text { Yes } \\
\text { Yes } \\
\text { Yes } \\
\text { Yes }\end{array}$ \\
\hline $\begin{array}{l}\text { Observations } \\
R^{2}\end{array}$ & $\begin{array}{c}9,393 \\
0.77\end{array}$ & $\begin{array}{c}9,393 \\
0.77\end{array}$ & $\begin{array}{c}4,043 \\
0.75\end{array}$ & $\begin{array}{c}4,043 \\
0.75\end{array}$ \\
\hline
\end{tabular}

Standard errors are reported in parentheses. The standard errors are clustered at the firm level.

FXdebt $t_{i}$ represent the short-term dollar debt share of a given firm defined as before.

${ }^{*} p<0.10,{ }^{* *} p<0.05,{ }^{* * *} p<0.01$.

In order to see the effect of such policies in our benchmark sample, we have added the most commonly used FXI variable to our regressions, that is the FX reserves-to-GDP ratio. As we show in Table 16, our results are robust and FXI itself has a strong negative effect on firm leverage. 
Table 16: Benchmark Results with FXI

Dependent variable: Financial debt/assets $s_{i, j, c, t}$

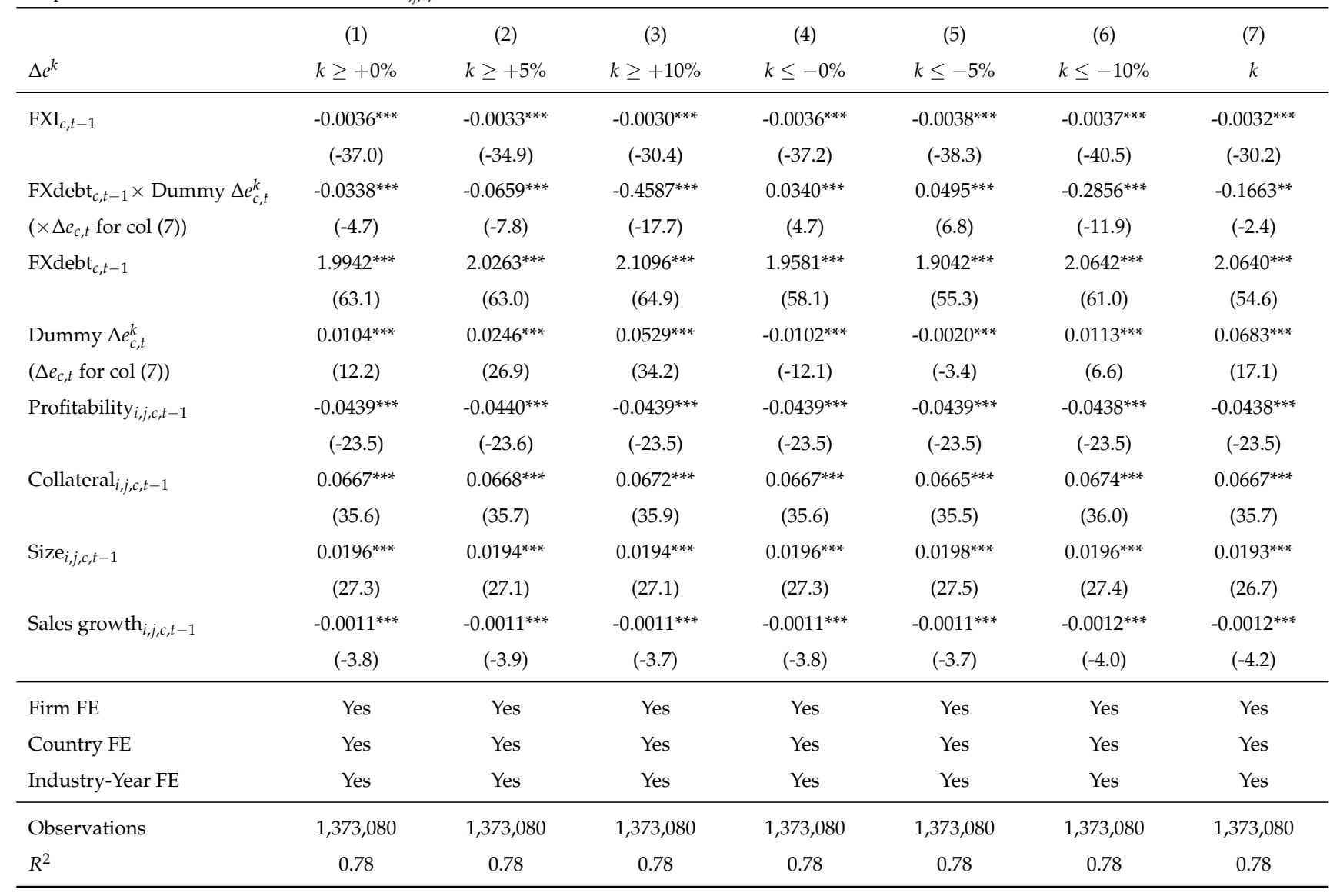

$\mathrm{FXI}_{c, t-1}$ is the foreign reserves-to-GDP ratio in each country in year $t-1$. See notes to the previous tables for all other variables. $\mathrm{t}$-stats based on clustered standard errors are in parentheses.

${ }^{*} p<0.10,{ }^{* *} p<0.05,{ }^{* * *} p<0.01$.

The results are robust to using alternative specifications in benchmark Table 6 and Table 7 as shown below in Table 17.

FXI policies differ across countries in their timing and nature and hence the results above might be specific to our 10 EMEs. Hence we have also run a similar regression for the larger sample of 42 economies with aggregate FX debt data from BIS, including our 10 emerging markets, using over 7 million firms from these countries. We have obtained an insignificant result of FXI as shown in Table 18, column (1). When we separate the 42 economies into high and low FX debt in the first year of the sample (instead of controlling FX debt in the regressions), then we find a weak positive effect in the high FX debt economies as shown in column (2). 
Table 17: Benchmark Results with FXI: Robustness

Dependent variable: Financial debt/assets ${ }_{i, j, c, t}$

\begin{tabular}{|c|c|c|c|c|c|c|c|}
\hline$\Delta e^{k}$ & $\begin{array}{c}(1) \\
k \geq+0 \%\end{array}$ & $\begin{array}{c}(2) \\
k \geq+5 \%\end{array}$ & $\begin{array}{c}(3) \\
k \geq+10 \%\end{array}$ & $\begin{array}{c}(4) \\
k \leq-0 \%\end{array}$ & $\begin{array}{c}(5) \\
k \leq-5 \%\end{array}$ & $k \leq-10 \%$ & $\begin{array}{l}(7) \\
k\end{array}$ \\
\hline \multicolumn{8}{|c|}{ Benchmark Results: FX Debt-Excluding Government FX Bonds } \\
\hline $\mathrm{FXI}_{c, t-1}$ & $\begin{array}{c}-0.0036^{* * *} \\
(-38.4)\end{array}$ & $\begin{array}{c}-0.0032^{* * *} \\
(-34.8)\end{array}$ & $\begin{array}{c}-0.0029^{* * *} \\
(-29.6)\end{array}$ & $\begin{array}{c}-0.0036^{* * *} \\
(-38.5)\end{array}$ & $\begin{array}{c}-0.0034^{* * *} \\
(-35.9)\end{array}$ & $\begin{array}{c}-0.0039^{* * *} \\
(-44.3)\end{array}$ & $\begin{array}{c}-0.0028^{* * *} \\
(-27.0)\end{array}$ \\
\hline $\begin{array}{l}\text { FXdebt }{ }_{c, t-1} \times \text { Dummy } \Delta e_{c, t}^{k} \\
\left(\times \Delta e_{c, t} \text { for } \operatorname{col}(7)\right)\end{array}$ & $\begin{array}{c}-0.1385^{* * *} \\
(-10.5)\end{array}$ & $\begin{array}{c}-0.3135^{* * *} \\
(-19.6)\end{array}$ & $\begin{array}{l}-0.9817^{* * *} \\
(-17.6)\end{array}$ & $\begin{array}{l}0.1386^{* * *} \\
(10.5)\end{array}$ & $\begin{array}{l}0.2682^{* * *} \\
(18.5)\end{array}$ & $\begin{array}{c}-0.0576^{*} \\
(-1.8)\end{array}$ & $\begin{array}{c}-1.7370^{* * *} \\
(-14.6)\end{array}$ \\
\hline FXdebt ${ }_{c, t-1}$ & $\begin{array}{l}2.4833^{* * *} \\
(70.6)\end{array}$ & $\begin{array}{l}2.5368^{* * *} \\
(71.2)\end{array}$ & $\begin{array}{l}2.6067^{* * *} \\
(71.7)\end{array}$ & $\begin{array}{l}2.3437^{* * *} \\
(65.6)\end{array}$ & $\begin{array}{l}2.3409^{* * *} \\
(62.8)\end{array}$ & $\begin{array}{l}2.3817^{* * *} \\
(67.4)\end{array}$ & $\begin{array}{l}2.5748^{* * *} \\
\quad(62.7)\end{array}$ \\
\hline $\begin{array}{l}\text { Dummy } \Delta e_{c, t}^{k} \\
\left(\Delta e_{c, t} \text { for } \operatorname{col}(7)\right)\end{array}$ & $\begin{array}{l}0.0134^{* * *} \\
(13.8)\end{array}$ & $\begin{array}{l}0.0386^{* * *} \\
(36.2)\end{array}$ & $\begin{array}{l}0.0785^{* * *} \\
(29.9)\end{array}$ & $\begin{array}{c}-0.0134^{* * *} \\
(-13.8)\end{array}$ & $\begin{array}{c}-0.0156^{* * *} \\
(-18.6)\end{array}$ & $\begin{array}{c}-0.0091^{* * *} \\
(-5.2)\end{array}$ & $\begin{array}{l}0.1582^{* * *} \\
\quad(28.6)\end{array}$ \\
\hline \multicolumn{8}{|l|}{ Benchmark Results: FX Loans } \\
\hline $\mathrm{FXI}_{c, t}$ & $\begin{array}{c}-0.0037^{* * *} \\
(-40.2)\end{array}$ & $\begin{array}{c}-0.0034^{* * *} \\
(-36.7)\end{array}$ & $\begin{array}{c}-0.0030^{* * *} \\
(-31.5)\end{array}$ & $\begin{array}{c}-0.0037^{* * *} \\
(-40.1)\end{array}$ & $\begin{array}{c}-0.0034^{* * *} \\
(-36.6)\end{array}$ & $\begin{array}{c}-0.0038^{* * *} \\
(-44.0)\end{array}$ & $\begin{array}{c}-0.0029^{* * *} \\
(-29.1)\end{array}$ \\
\hline $\begin{array}{l}\text { FXloan } \\
\left(\times \Delta e_{c, t-1} \text { for } \operatorname{col}(7)\right)\end{array}$ & $\begin{array}{c}-0.0868^{* * *} \\
(-5.5)\end{array}$ & $\begin{array}{c}-0.5032^{* * *} \\
(-25.1)\end{array}$ & $\begin{array}{c}-1.3152^{* * *} \\
(-20.9)\end{array}$ & $\begin{array}{l}0.0926^{* * *} \\
(5.9)\end{array}$ & $\begin{array}{l}0.2831^{* * *} \\
(15.0)\end{array}$ & $\begin{array}{l}0.0907^{* * *} \\
(2.6)\end{array}$ & $\begin{array}{c}-2.9864^{* * *} \\
(-21.1)\end{array}$ \\
\hline FXloan $_{c, t-1}$ & $\begin{array}{l}2.6705^{* * *} \\
(73.7)\end{array}$ & $\begin{array}{l}2.7798^{* * *} \\
(75.9)\end{array}$ & $\begin{array}{l}2.7998^{* * *} \\
(74.9)\end{array}$ & $\begin{array}{l}2.5831^{* * *} \\
(70.4)\end{array}$ & $\begin{array}{l}2.5962^{* * *} \\
(67.3)\end{array}$ & $\begin{array}{l}2.5981^{* * *} \\
(71.6)\end{array}$ & $\begin{array}{l}2.7641^{* * *} \\
\quad(68.6)\end{array}$ \\
\hline $\begin{array}{l}\text { Dummy } \Delta e_{c, t}^{k} \\
\left(\Delta e_{c, t} \text { for } \operatorname{col}(7)\right)\end{array}$ & $\begin{array}{c}0.0048^{* * *} \\
(5.4)\end{array}$ & $\begin{array}{c}0.0362^{* * *} \\
(36.9)\end{array}$ & $\begin{array}{c}0.0700^{* * *} \\
(30.9)\end{array}$ & $\begin{array}{c}-0.0054^{* * *} \\
(-6.1)\end{array}$ & $\begin{array}{c}-0.0132^{* * *} \\
(-16.3)\end{array}$ & $\begin{array}{c}-0.0174^{* * *} \\
(-11.6)\end{array}$ & $\begin{array}{c}0.1640^{* * *} \\
(30.8)\end{array}$ \\
\hline Firm controls & Yes & Yes & Yes & Yes & Yes & Yes & Yes \\
\hline Firm FE & Yes & Yes & Yes & Yes & Yes & Yes & Yes \\
\hline Country FE & Yes & Yes & Yes & Yes & Yes & Yes & Yes \\
\hline Industry-Year FE & Yes & Yes & Yes & Yes & Yes & Yes & Yes \\
\hline
\end{tabular}

$\mathrm{FXI}_{c, t-1}$ is the foreign reserves-to-GDP ratio in each country in year $t-1$. See notes to the previous tables for all other variables. $\mathrm{t}$-stats based on clustered standard errors are in parentheses.

${ }^{*} p<0.10,{ }^{* *} p<0.05,{ }^{* * *} p<0.01$.

Table 18: The effect of FXI: Larger Sample of Economies

Dependent variable: Financial debt/assets $i_{i, j, c, t}$

\begin{tabular}{lccc}
\hline & $\begin{array}{c}(1) \\
\text { All countries }\end{array}$ & $\begin{array}{c}(2) \\
\text { High FX debt } \\
\text { economies }\end{array}$ & $\begin{array}{c}\text { Low FX debt } \\
\text { economies }\end{array}$ \\
\hline FXI $_{c, t-1}$ & 0.13 & $0.07^{*}$ & 0.01 \\
& $(0.09)$ & $(0.04)$ & $(0.10)$ \\
\hline Firm Controls & Yes & Yes & Yes \\
Firm FE & Yes & Yes & Yes \\
Country FE & Yes & Yes & Yes \\
Industry-Year FE & Yes & Yes & Yes \\
\hline Observations & $7,020,054$ & $1,284,781$ & $4,108,779$ \\
$R^{2}$ & 0.78 & 0.79 & 0.82 \\
\hline
\end{tabular}

Firm clustered standard errors in parentheses.

${ }^{*} p<0.10,{ }^{* *} p<0.05,{ }^{* * *} p<0.01$. 


\section{Conclusion}

This paper quantifies the response of firm leverage to exchange rate fluctuations. When home currency appreciates, firms that hold FX debt and local currency assets observe higher net worth as appreciation lowers the value of their FX debt. These firms can borrow more as a result. When home currency depreciates, the reverse happens and firms have to de-lever with a negative shock to their balance sheets.

Using firm-level data for leverage from 10 emerging market economies during the period from 2002 to 2015, we show that firms operating in countries whose non-financial sectors hold more of the debt in FX, increase (decrease) their leverage relatively more after home currency appreciations (depreciations). The effect of a depreciation is quantitatively larger than that of an appreciation, especially for depreciations larger than 10 per cent. By separating FX debt of the corporate sector into loans and bonds, we show that our results are due to loans in FX, rather than bonds. Instead of proxying firm-level FX debt with the non-financial sectors' aggregate FX debt, we also use actual firm-level FX debt data from 4 emerging countries and show that our results hold. Furthermore, we show a negative significant effect of FXI policies-that are designed to limit exchange rate fluctuations-on firm leverage in our 10 emerging market economies and no effect of such policies in a larger sample of 42 economies.

Our findings have important policy implications. It is crucial to monitor firms' FX exposure and in particular, the extent of currency mismatch on their balance sheet. We show that currency appreciations combined with higher levels of FX exposure can prompt firms to increase their leverage during good times (risk taking), but that such firms are likely to become subject to de-leveraging pressures when their local currency depreciates. When the firms suffer from FX valuation losses and FX funding strains, the national authorities are often expected to step in to provide FX liquidity to these firms either directly or indirectly through their banks to minimize the negative impact on growth. Such circumstances require consideration of the adequate amount of available FX safety net in proportion to the size of FX mismatches both in aggregate and across firms. It might be hard to provide this type of safety net for many emerging market economies, especially during crises. Macroprudential policies to prevent the accumulation of un-hedged FX debt in the domestic economy during the booms might be a better approach to deal with such vulnerabilities. ${ }^{17}$

\footnotetext{
${ }^{17}$ Kalemli-Ozcan (2019) shows that using monetary policy to limit the exchange rate fluctuations during crises
} 


\section{Appendix}

We go through the following five steps to calculate FX debt at the firm level:

1. Total FX debt in an economy. The BIS Global Liquidity Indicator (GLI) database provides total FX debt data at the country level, which consist of data on debt securities denominated in the US dollar, euro and Japanese yen and issued by the non-financial sector entities in a country and data on bank loans denominated in the US dollar, euro and Japanese yen and extended to the non-bank sector entities in the country. Bank loans include both cross-border bank loans and locally-extended bank loans. The non-financial sector includes non-financial firms, households and the government, while the non-bank sector includes non-bank financial firms in addition to the non-financial sector. The debt securities data are from the BIS International Debt Securities Statistics, while the bank loan data from the BIS Locational Banking Statistics. The BIS International Debt Securities Statistics also provide data on the value of FX-denominated debt securities issued by the government. In order to focus on FX-denominated debt securities issued by nonfinancial firms, we subtract the value of FX-denominated debt securities issued by the government from total FX debt. When we use the country-level total FX debt, the values denominated in the euro and Japanese yen are converted into those in the US dollar using the quarter-end exchange rate.

2. Total credit to the non-financial sector. The BIS Total Credit database provides data on total credit to the non-financial sector. Total credit includes all forms of credit (including both loans and debt securities) extended by banks and non-banks in all currencies. The database also provide data on total credit broken down into the following three sectors: non-financial firms, households and the government.

3. Based on (1) and (2), we compute the FX debt share of each country as the ratio of FX debt to total credit to the non-financial sector. Note that both FX debt and total credit include both loans and debt securities.

4. Firm-level total debt. From the ORBIS database, we obtain the value of total debt outstanding reported in the balance sheets of each firm's annual reports.

in countries with high levels of FX debt can be counter-productive.

CInternational Monetary Fủhd. Not for Redistribution 
5. Finally, we multiply the FX debt share for an economy by firm-level total debt for all firms located in the economy, to estimate the amount of firm-level FX debt outstanding. 


\section{References}

Adrian, Tobias and Hyun Song Shin, "Procyclical leverage and Value-at-Risk," NBER Working Papers 18943, 2013.

Aghion, Philippe, Philippe Bacchetta, and Abhijit Banerjee, "A simple model of monetary policy and currency crises," European Economic Review, 2000, 44, 728-738.

${ }_{-}$, , $_{\text {, and }}$, , "Currency crises and monetary policy in an economy with credit constraints," European Economic Review, 2001, 45(7), 1121-1150.

Aguiar, Mark, "Investment, devaluation, and foreign currency exposure: the case of Mexico," Journal of Development Economics, 2005, 78, 95-113.

Albuquerque, Rui and Hugo A. Hopenhayn, "Optimal Lending Contracts and Firm Dynamics," The Review of Economic Studies, 2004, 71 (2), 285-315.

Avdjiev, Stefan, Cathérine Koch, and Hyun Song Shin, "Exchange rates and the transmission of global liquidity," Mimeo, 2018.

_ , Valentina Bruno, Cathérine Koch, and Hyun Song Shin, "The dollar exchange rate as a global risk factor: evidence from investment," BIS Working Papers 695, 2018.

_ , Wenxin Du, Cathérine Koch, and Hyun Song Shin, "The dollar, bank leverage and deviations from covered interest parity," American Economic Review: Insights, 2019, 1(2), 193-208.

Bénétrix, Agustín, Philip Lane, and Jay Shambaugh, "International currency exposures, valuation effects and the global financial crisis," NBER Working Papers 20820, 2015.

Bleakley, Hoyt and Kevin Cowan, "Corporate Dollar Debt and Depreciations: Much Ado About Nothing?", Review of Economics and Statistics, 2008, 90 (4), 612-626.

Bruno, Valentina and Hyun Song Shin, "Cross-border banking and global liquidity," Review of Economic Studies, 2015a, 82(2), 535-564.

_ and _ , "Capital flows and the risk-taking channel of monetary policy," Journal of Monetary Economics, 2015b, 71, 119-132.

Burnstein, Ariel and Gita Gopinath, "International prices and exchange rates," Handbook of International Economics, 4th edition, Elsevier 4:391-451, 2014.

Calvo, Guillermo A., "Capital flows and capital-market crises: the simple economics of sudden stops," Journal of Applied Economics, 1998, 1, 35-54.

- and Carmen M. Reinhart, "Fear of floating," Quarterly Journal of Economics, 2002, 117(2), 379-408.

Céspedes, Luis Felipe, Roberto Chang, and Andrés Velasco, "Balance sheets and exchange rate policy," American Economic Review, 2004, 94(4), 1183-1193. 
Diamond, Douglas W., Yunzhi Hu, and Raghuram G. Rajan, "The spillovers from easy liquidity and the implications for the multilateralism," paper presented at the Mundell Fleming Lecture delivered by Raghuram Rajan at the International Monetary Fund Annual Research Conference on 1 November 2018.

Gopinath, Gita, "The international price system," Jackson Hole Symposium Proceedings, NBER Digest, January 2016.

- and Brent Neiman, "Trade adjustment and productivity in large crises," American Economic Review, 2013, 104(3), 793-831.

_, Emine Boz, Camila Casas, Federico J. Diez, Pierre-Olivier Gourinchas, and Mikkel Plagborg-Moller, “Dominant currency paradigm," Mimeo, 2019.

Hofmann, Boris, Ilhyock Shim, and Hyun Song Shin, "Sovereign yields and the risk-taking channel of currency appreciation," BIS Working Papers 538, 2017.

${ }_{-},{ }_{-}$, and $\_$, "Bond risk premia and the exchange rate," BIS Working Papers 775, 2019.

Kalemli-Ozcan, Sebnem, "U.S. monetary policy and international risk spillovers," paper presented at Jackson Hole Symposium 2019, 2019.

-, Bent Sorensen, Carolina Villegas-Sanchez, Vadym Volosovych, and Sevcan Yesiltas, "How to construct nationally representative firm-level data from the ORBIS global database," NBER Working Papers 21558, 2015.

_ , Herman Kamil, and Carolina Villegas-Sanchez, "What hinders investment in the aftermath of financial crises: insolvent firms or illiquid banks?," Review of Economics and Statistics, 2016, 98(4), 756-769.

Kim, Yun Jung, Linda L. Tesar, and Jing Zhang, "The impact of foreign liabilities on small firms: Firm-level evidence from the Korean crisis," Journal of International Economics, 2015, 97, 209-230.

Krugman, Paul, "Balance sheets, the transfer problem, and financial crises," International Tax and Public Finance, 1999, 6, 459-472.

Lane, Philip and Jay Shambaugh, "Financial exchange rates and international currency exposures," American Economic Review, 2010, 100(1), 518-540.

Maggiori, Matteo, Brent Neiman, and Jesse Schreger, "International currencies and capital allocation," NBER Working Papers 24673, 2018.

Mendoza, Enrique G., "Sudden stops, financial crises, and leverage," American Economic Review, 2010, 100(5), 1941-66.

- and Vivian Z. Yue, "A general equilibrium model of sovereign default and business cycles," Quarterly Journal of Economics, 2012, 127(2), 889-946.

Rajan, Raguram G. and Luigi Zingales, "What do we know about capital structure? Some evidence from international data," Journal of Finance, 1995, 50(5), 1421-1460. 
Serena, Jose Maria and Ricardo Sousa, "Does exchange rate depreciation have contractionary effects on firm-level investment?," BIS Working Papers 624, 2017.

Tong, Hui and Shang-Jin Wei, "Endogenous corporate leverage response to a safer macro environment: The case of foreign exchange reserve accumulation," NBER Working Papers $26545,2019$. 